Article

\title{
Spatial Data Management and Numerical Modelling: Demonstrating the Application of the QGIS-Integrated FREEWAT Platform at 13 Case Studies for Tackling Groundwater Resource Management
}

Giovanna De Filippis ${ }^{1, * \mathbb{D}}$, Christos Pouliaris ${ }^{2}$, Daniel Kahuda ${ }^{3}$, Teodora Alexandra Vasile ${ }^{4}$, Valentina Adriana Manea ${ }^{4}$, Florian Zaun ${ }^{5}$, Björn Panteleit ${ }^{6}{ }^{\circ}$, Filiz Dadaser-Celik ${ }^{7}(\mathbb{D}$, Pio Positano ${ }^{8}$, Marco Saulo Nannucci ${ }^{8}$, Mykhailo Grodzynskyi ${ }^{9}$, Andres Marandi ${ }^{10}$, Manuel Sapiano ${ }^{11}$, Irena Kopač ${ }^{12}$, Andreas Kallioras ${ }^{2}{ }^{(0}$, Massimiliano Cannata ${ }^{13}{ }^{1}$, Youssef Filiali-Meknassi ${ }^{14}$, Laura Foglia ${ }^{5,15}$, Iacopo Borsi ${ }^{16}$ and Rudy Rossetto ${ }^{1}$ (D)

1 Institute of Life Sciences, Scuola Superiore Sant'Anna, Piazza Martiri della Libertà 33, 56127 Pisa, Italy; r.rossetto@santannapisa.it

2 Department of Geological Sciences, School of Mining and Metallurgical Engineering, National Technical University of Athens, Heroon Polytechneiou 9, 15780 Zografou, Athens, Greece; pouliaris@metal.ntua.gr (C.P.); kallioras@metal.ntua.gr (A.K.)

3 Department of Water Resources and Environmental Modeling, Faculty of Environmental Sciences, Czech University of Life Sciences Prague, Kamycka 129, 16500 Prague, Czech Republic; kahuda@fzp.czu.cz

4 National Institute of Hydrology and Water Management, Soseaua București-Ploiești 97E, 013686 Bucharest, Romania; vasile_teodora2011@yahoo.com (T.A.V.); manea.valentina90@gmail.com (V.A.M.)

5 Institut für Angewandte Geowissenschaften, Technische Universität Darmstadt, Schnittspahnstraße 9, 64287 Darmstadt, Germany; florian.zaun@googlemail.com (F.Z.); lfoglia@ucdavis.edu (L.F.)

6 Universität Bremen-Geologischer Dienst für Bremen, Leobener Str. 8, 28359 Bremen, Germany; bpanteleit@gdfb.de

7 Dept. of Environmental Engineering, Erciyes University, Talas Blv., 38039 Kayseri, Turkey; fdadaser@erciyes.edu.tr

8 Regione Toscana, Via di Novoli 26, 50127 Firenze, Italy; pio.positano@regione.toscana.it (P.P.); marco.nannucci@regione.toscana.it (M.S.N.)

9 Taras Shevchenko National University of Kyiv, Volodymyrska St 60, 01033 Kyiv, Ukraine; mgrodz@ukr.net

10 Geological Survey of Estonia, F. R. Kreutzwaldi 5, 44314 Rakvere, Estonia; andres.marandi@egt.ee

11 Energy and Water Agency, Qormi Road, 9043 Luqa, Malta; manuel.sapiano@gov.mt

12 Aneri Eco Ingineering, Maistrova ul. 4, 9250 Radenci, Slovenia; irena.kopac.ik@gmail.com

13 Institute of Earth Sciences, Scuola Universitaria Professionale della Svizzera Italiana, Campus Trevano, CH-6952 Canobbio, Switzerland; massimiliano.cannata@supsi.ch

14 UNESCO-IHP, Place de Fontenoy 7, 75007 Paris, France; y.filali-meknassi@unesco.org

15 Department of Land, Air and Water Resources, University of California, Davis, CA 95616, USA

16 TEA SISTEMI S.p.A., Via Ponte a Piglieri, 8, 56122 Pisa, Italy; iacopo.borsi@tea-group.com

* Correspondence: g.defilippis@santannapisa.it

Received: 24 October 2019; Accepted: 13 December 2019; Published: 20 December 2019 updates

\begin{abstract}
Because of the spatial nature of groundwater-related data and their time component, effective groundwater management requires the application of methods pertaining to the Information and Communication Technologies sector, such as spatial data management and distributed numerical modelling. The objective of this paper is to demonstrate the effectiveness of the QGIS-integrated FREEWAT platform and an approach combining spatial data management and numerical models to target groundwater management issues. FREEWAT is a free and open source platform integrated in a Geographic Information System environment and embedding tools for pre- and post-processing of
\end{abstract}


spatial data and integrating numerical codes for the simulation of the hydrological cycle, with a main focus on groundwater. To this aim, this paper briefly presents the FREEWAT platform, introduces the FREEWAT approach, and showcases 13 case studies in European and non-European countries where the FREEWAT platform was applied. Application of the FREEWAT platform to real-world case studies is presented for targeting management of coastal aquifers, ground- and surface-water interaction, climate change impacts, management of transboundary aquifers, rural water management and protection of groundwater-dependent ecosystems. In this sense, compared to other existing software suites, FREEWAT allows data analysis and visualization to accomplish each step of the modelling workflow, i.e., from data analytics, to conceptual model definition, to numerical modelling and reporting of results. The presented experiences demonstrate that improved access to data and the portability of models and models' results can help to promote water sustainability from the localto the basin-scale. Furthermore, FREEWAT may represent a valuable tool to target the objective of increasing the capabilities of public authorities and private companies to manage groundwater resources by means of up-to-date, robust, well-documented and reliable software, without entailing the need of costly licensing, nowadays seldom affordable by public water authorities. Based on the strengths highlighted, the FREEWAT platform is a powerful tool for groundwater resources management, and for data collection, sharing, implementation and comparison of scenarios, for supporting planning and decision-making.

Keywords: groundwater management; spatial database; QGIS; MODFLOW; FREEWAT

\section{Introduction}

The good status of groundwater resources in terms of quality and quantity is of outmost importance for the well-being of natural ecosystems and human life. Assuring good-quality water in the required amounts, while respecting the equilibrium of physical-chemical processes occurring at water-related ecosystems (e.g., in response to climate change), is a key point in the agenda of water managers dealing with water sustainability and groundwater resource management (GWRM) [1,2].

In Europe, the Water Framework Directive (WFD) [3] and daughter directives (i.e., Groundwater Directive [4]) are the reference regulations for planning and protection of freshwater resources. The WFD aims at achieving a "good status" for water bodies in Europe (from the ecological and chemical perspectives for surface waters, from the chemical and quantitative perspectives for groundwater) and to prevent any further deterioration.

The WFD and the Groundwater Directive oblige European Union (EU) member states to monitor surface water and groundwater bodies. In this sense, effective data collection and information sharing need to be guaranteed. These are key points for (i) achieving data consolidation, (ii) establishing monitoring and management protocols for the governance of water and the protection of water-related ecosystems, and (iii) devising joint modelling solutions for water planning [5].

Giving the spatial nature of groundwater-related data and their time component, effective GWRM requires the application of methods and software tools pertaining to the Information and Communication Technologies (ICT) sector such as spatial data management and environmental modelling [6]. Several efforts have been spent in the last decades to integrate ICT into a single groundwater management software solution. Several examples of numerical models integrated within a Geographic Information System (GIS) environment are available [7-16]. These solutions allow to complement the capabilities of GIS tools in supporting efficient management of spatial data and in extracting information, and the potentialities of numerical models in the field of water resource management. For a thorough review on the state-of-the-art integration of GIS and numerical models, see Rossetto et al. [17]. 
The objective of this paper is to demonstrate the effectiveness of the FREEWAT approach combining spatial data management and numerical models to target GWRM issues. FREEWAT [17] is a free and open source platform integrated in a GIS environment and embedding tools for pre- and post-processing of spatial data and numerical codes for the simulation of the hydrological cycle, with a main focus on groundwater. It is the main result of the HORIZON 2020 FREEWAT project (FREE and open source software tools for WATer resource management; www.freewat.eu), aimed at promoting GWRM by simplifying and strengthening the application of water-related regulations by means of ICT tools.

To this aim, this paper briefly presents the FREEWAT platform, introduces the FREEWAT approach and showcases a number of case studies in EU and non-EU countries where the FREEWAT platform was applied to devise strategies for GWRM. Case studies are divided into the following groundwater-related themes: (i) management of coastal aquifers; (ii) ground- and surface-water interactions; (iii) climate change; (iv) management of transboundary aquifers; (v) rural water management and protection of groundwater-dependent ecosystems.

\section{Materials and Methods}

\subsection{Overview of the FREEWAT Platform}

This section aims at providing an overview of the FREEWAT platform capabilities. Further details can be found in Rossetto et al. [17,18] and in Criollo et al. [19].

FREEWAT is a QGIS plugin which integrates free and open source software tools and modelling codes mostly for groundwater management and conjunctive use of ground- and surface-water. It is conceived as a unique environment in the QGIS GIS desktop [20], where data and information related to groundwater bodies characterization (e.g., sensor data, field data, information from the literature) can be (i) stored and analyzed with dedicated pre-processing tools to build robust hydrological conceptual models, (ii) processed by means of numerical models for the simulation of groundwater flow and related processes. Post-processing tools for visualization and analysis of model results complete the set of available tools.

Since FREEWAT is a QGIS-integrated platform, it allows the power of GIS tools for spatial data analysis to be coupled with that of process-based simulation models. This is accomplished by adopting a close/tight coupling approach [9], where GIS and the hydrological model engines work separately, but the first provides the interface where data are pre-processed, run and then visualized. Communication between the two engines occurs as the hydrological model runs: the GIS-integrated Graphical User Interface (GUI) generates input files, which are then read by the executable of the program code. The latter runs and produces output files which can be visualized in the GIS desktop. In FREEWAT, writing input files to modeling codes and analyzing model results are accomplished using the Python FloPy library [21-23].

The FREEWAT architecture is based on two main pillars (Figure 1):

(i) the GIS QGIS desktop;

(ii) a SpatiaLite relational database management system [24]. 


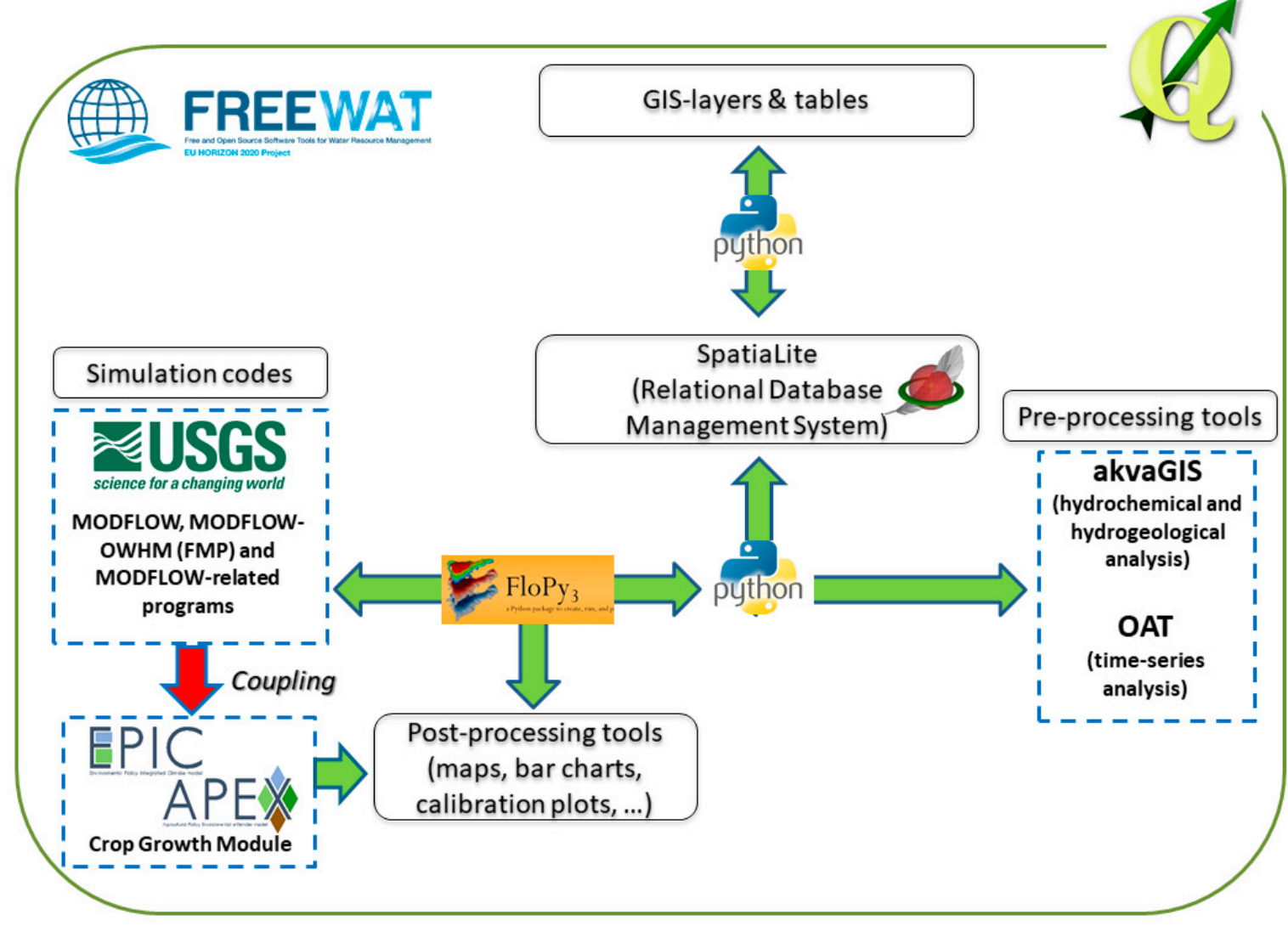

Figure 1. Simplified scheme of the FREEWAT architecture [18].

To these pillars, dedicated tools for pre-processing of field data and several process-based simulation models are added. The first consist in:

- $\quad$ the AkvaGIS for the analysis of hydrochemical and hydrogeological data [19];

- $\quad$ the Observation Analysis Tool (OAT) for time-series analysis [25].

Process-based models are mostly mutuated from the MODFLOW (Modular Ground-Water Model-the Ground-Water Flow Process) code and MODFLOW-related codes developed by the USGS (U.S. Geological Survey) family of codes:

- MODFLOW-2005 [26] for simulating groundwater flow in porous media, including ground- and surface-water interaction, vertical flow through the unsaturated zone, and seawater intrusion by adopting a 3D vertically integrated variable-density approach;

- MODFLOW-OWHM (One-Water Hydrologic Flow Model) [27], including the Farm Process (FMP) package to deal with conjunctive use of ground- and surface-water for water management issues;

- the Crop Growth Model based on the EPIC (Environmental Policy Integrated Climate) and APEX (Agricultural Policy / Environmental eXtender) family of models [28,29] to simulate crop yield at harvest as a function of the above-ground biomass;

- MODPATH [30] for particle tracking based on a purely advective transport process;

- ZONE BUDGET [31] to estimate the groundwater budget for model sub-regions;

- MT3DMS (Modular Three-Dimensional Multispecies Transport Model for Simulation of Advection, Dispersion, and Chemical Reactions of Contaminants in Groundwater Systems) [32] for simulating multi-species advective-dispersive transport in the saturated zone;

- MT3D-USGS [33], the most updated version of MT3DMS with new transport modelling capabilities, including simulation of solute transport in the unsaturated zone and mass exchange with surface water bodies; 
- the Unsaturated Solute Balance [34] module, which estimates purely advective transport of a contaminant through the vadose zone;

- $\quad$ SEAWAT [35] for the simulation of 3D, variable-density/-viscosity groundwater flow and multi-species transport;

- UCODE_2014 [36] for sensitivity analysis and inverse model calibration.

\subsection{Demonstration of FREEWAT Application at Selected Case Studies}

Application of the FREEWAT platform goes through the following steps (Figure 2), enhancing the workflow usually carried out by a groundwater expert when dealing with GWRM:

- data collection and storage via spatial database;

- data management by means of GIS tools for vector/raster analysis;

- definition of a conceptual model;

- $\quad$ translation of the conceptual model into a numerical model;

- model run;

- $\quad$ results' analysis and post-processing by means of GIS tools.

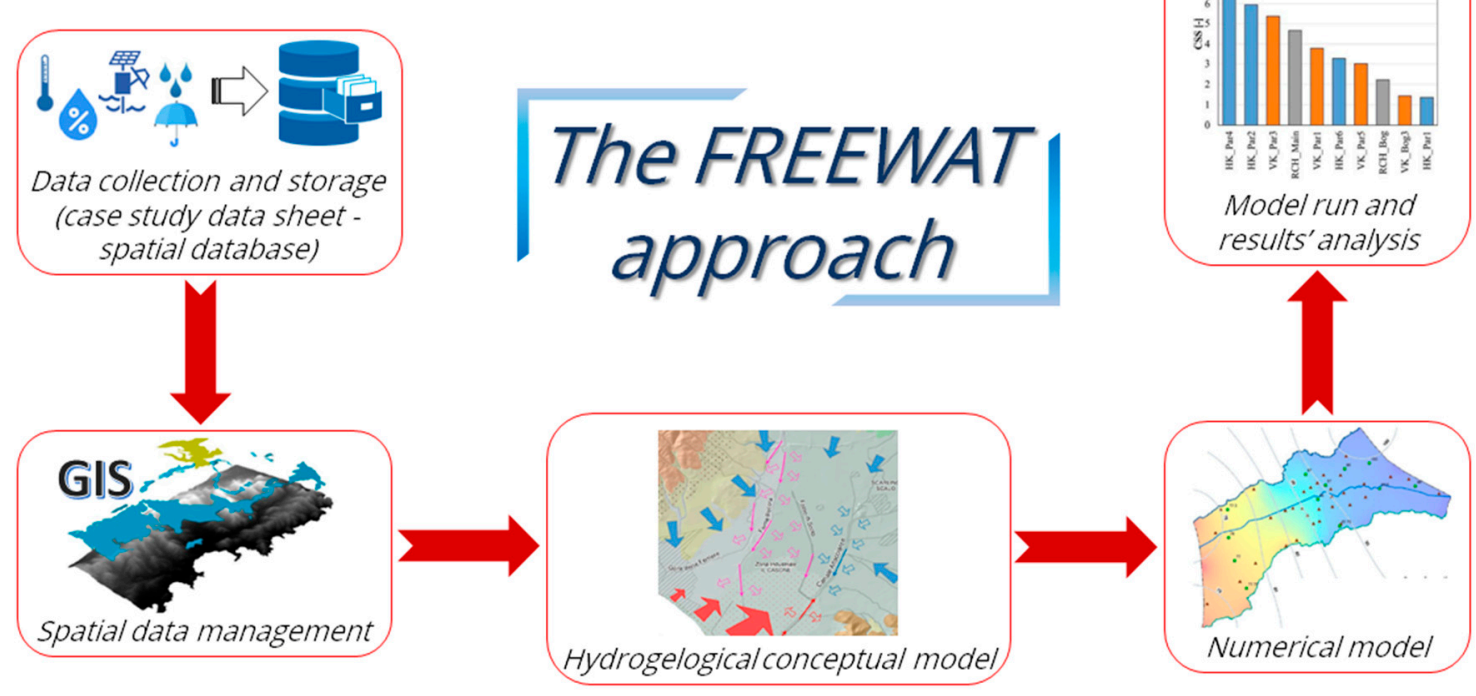

Figure 2. Sketch of the steps involved in the application of the FREEWAT platform for GWRM.

The FREEWAT approach and tools integrated within the FREEWAT platform have been applied at selected case studies in EU and non-EU countries during the H2020 FREEWAT project (2015-2017). Some of these are presented in this paper (Figure 3). For each case study, data were collected and a specific case study data sheet (detailing metadata for each of them) was compiled. As detailed in the above section, the FREEWAT platform integrates tools to serve all the above steps in a unique GIS environment. 


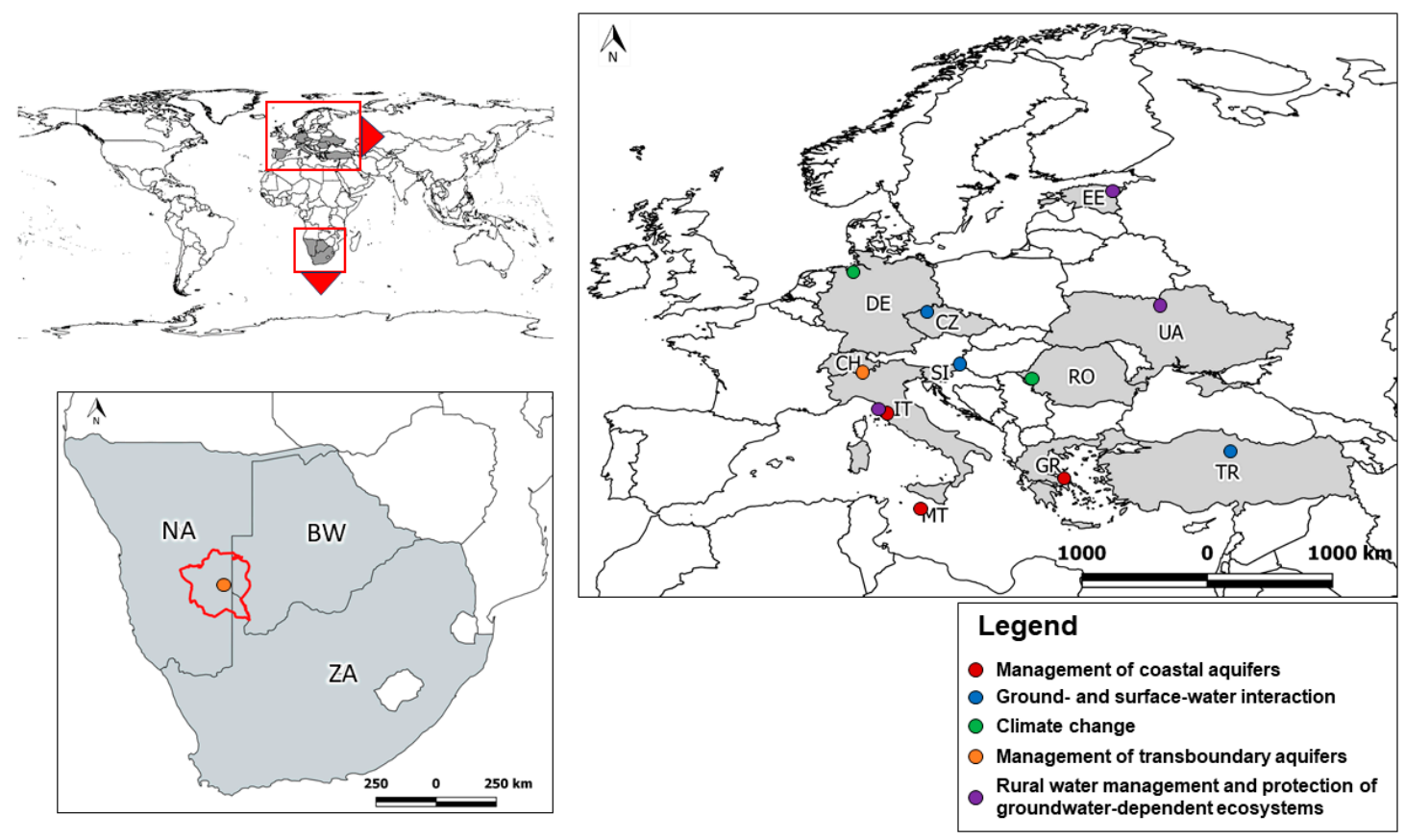

Figure 3. Location of the presented case studies (modified after Rossetto et al. [17]).

In the following sections, we grouped the case studies presented into five relevant macro-areas for groundwater management, depending on the case study objectives. Table 1 reports an overview of the objectives for each case study, the main model settings (i.e., space and time discretization of the models developed), and the FREEWAT pre-processing and modelling capabilities applied to each case study. About the spatial scale of the developed models, either local (of the order of 1-10 $\mathrm{km}^{2}$ ), regional (hundreds of $\mathrm{km}^{2}$ ) or transboundary (hundreds of thousands of $\mathrm{km}^{2}$ ) analysis were conducted. According to the objectives of the specific case study, the areas were discretized through fine or coarse grid cells (tens of meters to kilometers), resulting in model layers made of thousands to hundreds of thousand cells. Similarly, the vertical discretization was defined adopting two main approaches, i.e., following top and bottom surfaces of the hydrostratigraphic units, or slicing the hydrostratigraphic stack to get a finer discretization (e.g., for the analysis of saltwater intrusion). About the time scale of the processes investigated, the models were generally run over one or few more years with monthly stress periods, for assessment purposes or for testing the effectiveness of measures foreseen within River Basin Management Plans (RBMPs). Models developed for climate impacts projection reasons were run over much longer time scales (hundreds of years with longer stress periods, of the order of tens of years). 
Table 1. Overview of the objectives, the main model settings and the FREEWAT tools applied for each case study.

\begin{tabular}{|c|c|c|c|c|c|c|c|c|}
\hline Case Study & Country & Objectives & $\begin{array}{l}\text { Extent of the Study } \\
\text { Area }\left(\mathrm{km}^{2}\right)\end{array}$ & $\begin{array}{l}\text { Grid Cells Side } \\
\text { Length }(\mathrm{m})\end{array}$ & $\begin{array}{l}\text { Number of } \\
\text { Model Layers }\end{array}$ & $\begin{array}{l}\text { Number of } \\
\text { Grid Cells }\end{array}$ & $\begin{array}{l}\text { Length of the } \\
\text { Simulation and Number } \\
\text { of Stress Periods (SP) }\end{array}$ & $\begin{array}{l}\text { FREEWAT Modules } \\
\text { Applied }\end{array}$ \\
\hline Island of Gozo & Malta & $\begin{array}{l}\text { Assessing the impact of } \\
\text { climate change and human } \\
\text { activities on the } \\
\text { quantitative and qualitative } \\
\text { status of coastal aquifers }\end{array}$ & 80 & 50 & 22 & 49,824 & 12 months $-13 \mathrm{SP}$ & $\begin{array}{c}\text { AkvaGIS, } \\
\text { MODFLOW-2005, } \\
\text { MT3DMS, MODPATH, } \\
\text { SEAWAT }\end{array}$ \\
\hline $\begin{array}{l}\text { Follonica-Scarlino } \\
\text { plain }\end{array}$ & Italy & $\begin{array}{l}\text { Evaluating the effects of } \\
\text { alternative water } \\
\text { management strategies on } \\
\text { the quantitative status of } \\
\text { coastal aquifers }\end{array}$ & 78 & 100 & 4 & 11,990 & 12 months $-25 \mathrm{SP}$ & $\begin{array}{c}\text { AkvaGIS, OAT, } \\
\text { MODFLOW-2005, } \\
\text { MODPATH, } \\
\text { MODFLOW-OWHM, } \\
\text { UCODE_2014, ZONE } \\
\text { BUDGET }\end{array}$ \\
\hline Lavrion area & Greece & $\begin{array}{l}\text { Evaluating the effects of } \\
\text { Managed Aquifer Recharge } \\
\text { strategies on seawater } \\
\text { intrusion in coastal areas }\end{array}$ & 60 & 50 & 2 & 23,661 & 28 months $-28 \mathrm{SP}$ & $\begin{array}{c}\text { OAT, MODFLOW-2005, } \\
\text { UCODE_2014, ZONE } \\
\text { BUDGET }\end{array}$ \\
\hline Vrbanski plato & Slovenia & $\begin{array}{l}\text { Investigating the impacts of } \\
\text { polluting urban activities } \\
\text { on groundwater quality }\end{array}$ & 7 & 5 & 1 & 576,000 & 36 months $-12 \mathrm{SP}$ & $\begin{array}{c}\text { AkvaGIS, OAT, } \\
\text { MODFLOW-2005, } \\
\text { MT3DMS, MODPATH, } \\
\text { UCODE_2014, ZONE } \\
\text { BUDGET }\end{array}$ \\
\hline Palas basin & Turkey & $\begin{array}{l}\text { Analyzing the relationship } \\
\text { between ground- and } \\
\text { surface-water and the } \\
\text { effects of agricultural water } \\
\text { use in lacustrine } \\
\text { ecosystems }\end{array}$ & 480 & 250 & 2 & 16,416 & 12 months- $1 \mathrm{SP}$ & $\begin{array}{l}\text { MODFLOW-2005, } \\
\text { MODFLOW-OWHM }\end{array}$ \\
\hline
\end{tabular}


Table 1. Cont

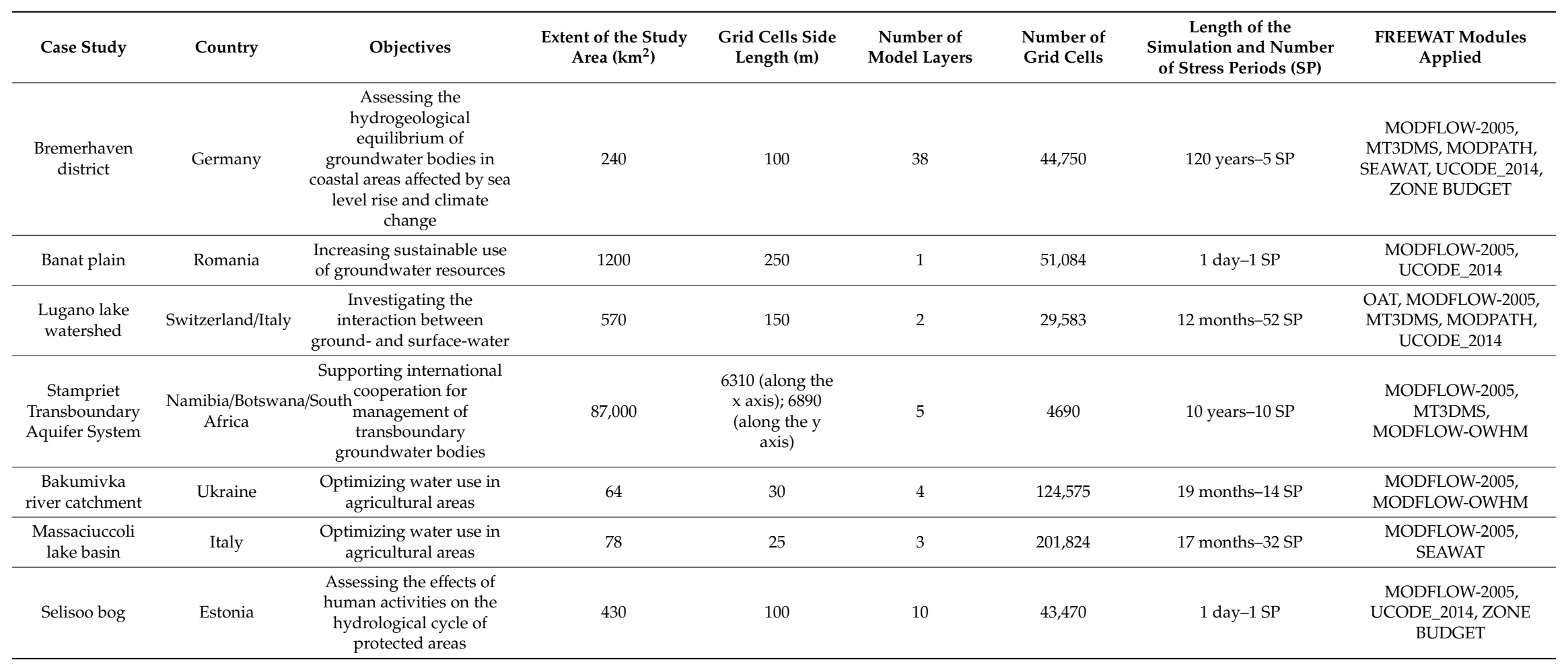




\subsection{Management of Coastal Aquifers}

Saltwater intrusion is a major concern in coastal areas worldwide. Under natural conditions, a density gradient occurs between fresh- and salt-water, resulting in a mixing zone (transition zone), whose thickness depends on the hydrodynamics of the aquifer. Such equilibrium is threatened by several factors: the sea-level rise and variations in recharge rate [37], and the unplanned exploitation of groundwater to meet the growing demand of more than two-thirds of the world's population living in coastal areas [38]. A number of literature papers are available about methodologies $[39,40]$ and case study examples [41-43] related to the topic of management of coastal aquifers.

FREEWAT capabilities were tested at three case studies to deal with this theme in Malta, Italy, and Greece.

\subsubsection{Island of Gozo, Malta}

The island of Gozo is the second largest island of the Maltese archipelago. Since it is characterized by scarce surface-water resources, water-demanding activities mostly rely on groundwater, which is hosted in the mean sea-level aquifer (MSLA) system. The MSLA system takes the shape of a freshwater lens floating above saltwater. The occurrence of groundwater abstractions threatens the hydrodynamic balance at the saltwater/freshwater interface, triggering intrusion of saltwater [44]. According to Malta's 2nd Water Catchment Management Plan (WCMP) [45], the Gozo MSLA system is in poor quantitative status and a deep assessment of its evolution in response to climate change and overexploitation is necessary, in order to identify management strategies to fulfil WCMP requirements.

In this framework, the FREEWAT platform was applied to simulate density-dependent flow in the MSLA system, in order to assess the impact of groundwater management strategies envisaged within the WCMP on the quantitative and qualitative status of this groundwater body. For the modeling purposes, model implementation within a GIS environment was particularly effective, as the stack of hydrogeological units was "sliced" in the vertical plane to represent the geological variability of the MSLA system.

Model results (Figure 4a, reference scenario under current abstraction conditions) showed that current groundwater abstraction rates affect the hydrogeological equilibrium of the MSLA on the regional scale, resulting in an overall lowering of the hydraulic head (up to $1.8 \mathrm{~m}$ in the central part of the island and $2.5 \mathrm{~m}$ in the south-eastern part, where the highest abstraction rates are located) with respect to pre-abstraction conditions. Furthermore, according to the calculated water budget in steady-state conditions, groundwater discharge towards the coast accounts for about $50 \%$ of the mean annual recharge by rainfall.

Two scenarios were also simulated. These aimed at assessing the impact of reducing public abstraction by $50 \%$ or of decreasing distributed recharge by $20 \%$. The first scenario (Figure $4 \mathrm{~b}$ ) resulted in a recovery of the piezometric head by about $0.2 \mathrm{~m}$ in the central part of the island and even more than $1 \mathrm{~m}$ in the south-eastern part. From the perspective of the model balance, this resulted in an increased groundwater discharge at the coast by about $1 \mathrm{Mm}^{3} /$ year. On the other hand, the second scenario posed quite severe conditions, as the piezometric head would undergo a decrease up to $2 \mathrm{~m}$ under extreme climate change conditions.

The developed GIS-supported numerical model represents a first test phase for conceptual understanding of the Gozo MSLA system and a valuable predictive tool. New data will allow the built spatial database to be populated and the quality of the dataset to be verified and improved while providing new information to constrain the simulated predictions. 


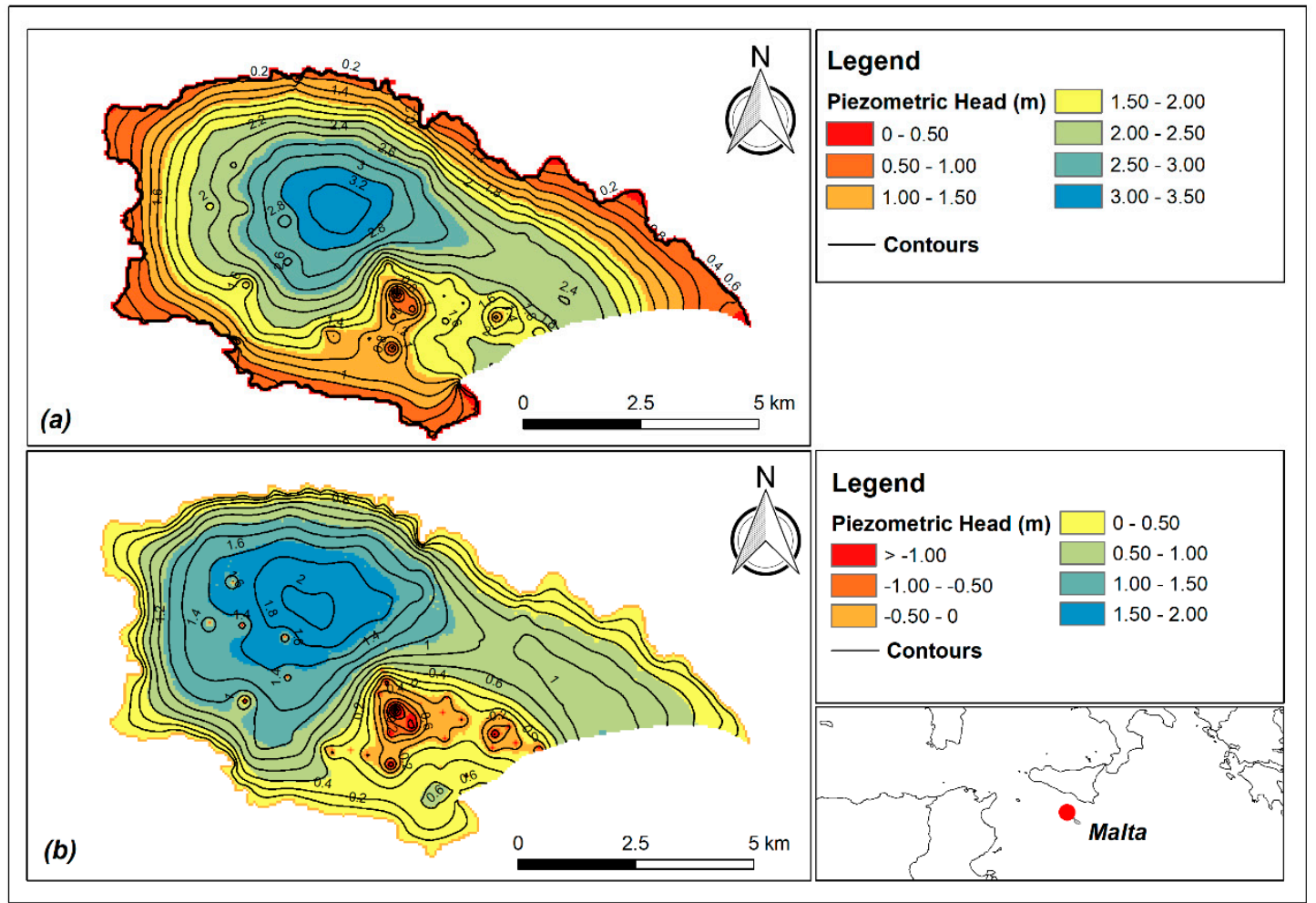

Figure 4. Model results of the reference scenario under current abstraction conditions (a) and of the first scenario (b).

\subsubsection{Follonica-Scarlino Plain, Italy}

The Follonica-Scarlino aquifer system is located in the southern part of the Tuscany region (central Italy), in the lower coastal plain of the Pecora river. The area is $78 \mathrm{~km}^{2}$ wide and belongs to the "Colline Metallifere" pyrite-based metals district, where extensive mining and metallurgical activities took place since the Etruscan-Roman times. The Follonica-Scarlino hydrological system includes a multilayer aquifer mostly exploited for industrial purposes; civil water supply during the summer season is also significant. According to the local RBMP [46], the Follonica-Scarlino aquifer shows an important quantitative gap. In view of achieving a "good" quantitative status by 2027 (as indicated in the RBMP itself), the local river basin authority designed various measures to cope with groundwater depletion, among which a desalination plant.

Application of the FREEWAT platform to the Follonica-Scarlino aquifer system [47] aimed at assessing the effects of alternative water management strategies on the quantitative status of the groundwater body. Two scenarios were simulated to achieve the aforementioned objectives. In the first scenario, the presence of a desalination plant was simulated as foreseen in the RBMP. This would take on the role of 11 pumping wells currently used for drinking water supply, thus potentially reducing groundwater abstraction of $0.5 \mathrm{Mm}^{3} /$ year. Comparisons were made on water budgets and the simulated piezometric head between the current state (with supply wells in use) and the scenario with the supply wells closed and the desalination plant in operation. Results showed that replacing the well field with a desalination plant for drinking water supply would have positive effects (i.e., rise of the water table of about $0.5 \mathrm{~m}$ ) only at the location of the well field (Figure $5 \mathrm{a}$ ). In the second scenario, reuse of the Gavorrano mine drainage water for industrial purposes (average total flow rate of $2.4 \mathrm{Mm}^{3}$ /year) was simulated with the scope of replacing withdrawals from wells located in the industrial area of "Casone", in the middle of the plain. Simulation results demonstrated the potential advantage of adopting such management strategy: even using only $50 \%$ of the water drained from the 
mine (accounting for a total of $2.4 \mathrm{Mm}^{3} / \mathrm{y}$ ), the minimum piezometric level simulated at the "Casone" area would disappear (Figure $5 b$ ).
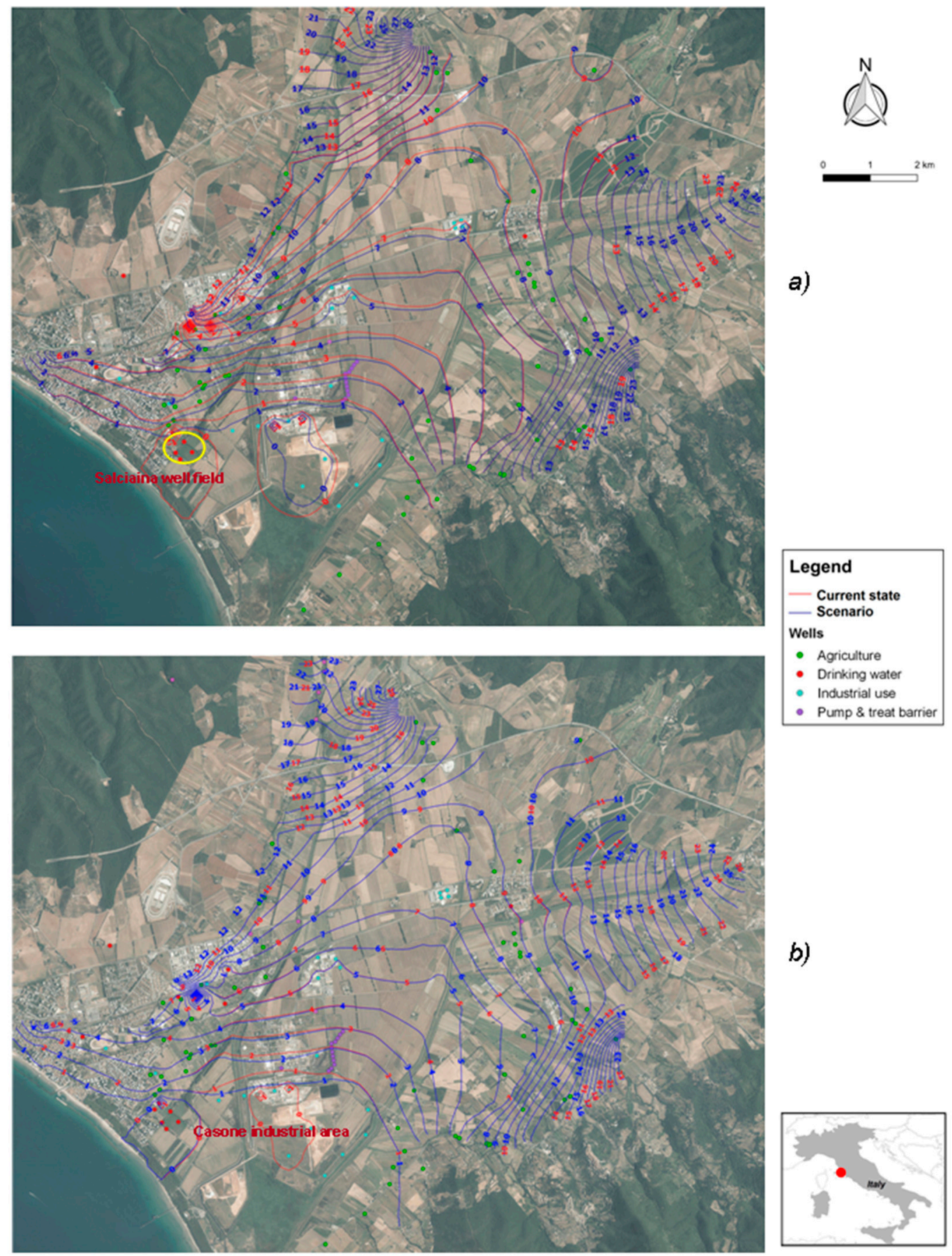

b)

Figure 5. Simulated hydraulic head for (a) the first management scenario (comparison between the current state, with drinking wells in use, and the state with the desalination plant active) and (b) the second management scenario (comparison between the current state, with industrial wells in use, and the state where the Gavorrano mine drainage water is reused).

This modelling experience proved the importance of the spatial database collected, organized and distributed by Regione Toscana through the webGIS Geoscopio [48] and the regional hydrological service (https://sir.toscana.it/) in an applicative environment. It also allowed to harmonize a large 
amount of data about the aquifer system under examination and to create a shared knowledge about the spatial features of the groundwater resource in the study area.

\subsubsection{Lavrion Area, Greece}

Lavrion is located in the south-eastern, coastal zone of Attica (Greece), where the groundwater resources are mainly used for agricultural purposes. The hydrogeological setting of the Lavrion catchment consists of a multi-layer system with two aquifers, one made of alluvial deposits, and one hosted in karstic marble formations, bounded at the bottom by an impermeable schist formation [49]. The aquifers suffer from water shortage due to overexploitation, low precipitation and high evapotranspiration rates and seawater intrusion.

The main objective of this modeling experience was to evaluate the impact of a Soil-Aquifer-Treatment (SAT) system for increasing piezometric levels to combat seawater intrusion.

The model domain extends up to about $60 \mathrm{~km}^{2}$ and a groundwater flow model was run in transient state spanning over two years. Different water management scenarios were developed, according to different effluent rates provided by the wastewater treatment plant of the Lavrion municipality, that were used as input for aquifer recharge schemes through the SAT system. The volumes that were used ranged between $0.8 \mathrm{Mm}^{3} /$ year and $1.5 \mathrm{Mm}^{3} /$ year.

As a result of the scenarios, the capacity of the aquifer to receive the different amount of recharge water was modeled. Depending on the recharge rates infiltrated through the SAT system, the groundwater level would increase up to $1.57 \mathrm{~m}$ close to the coast, thus producing a natural barrier to counteract seawater intrusion (Figure 6).
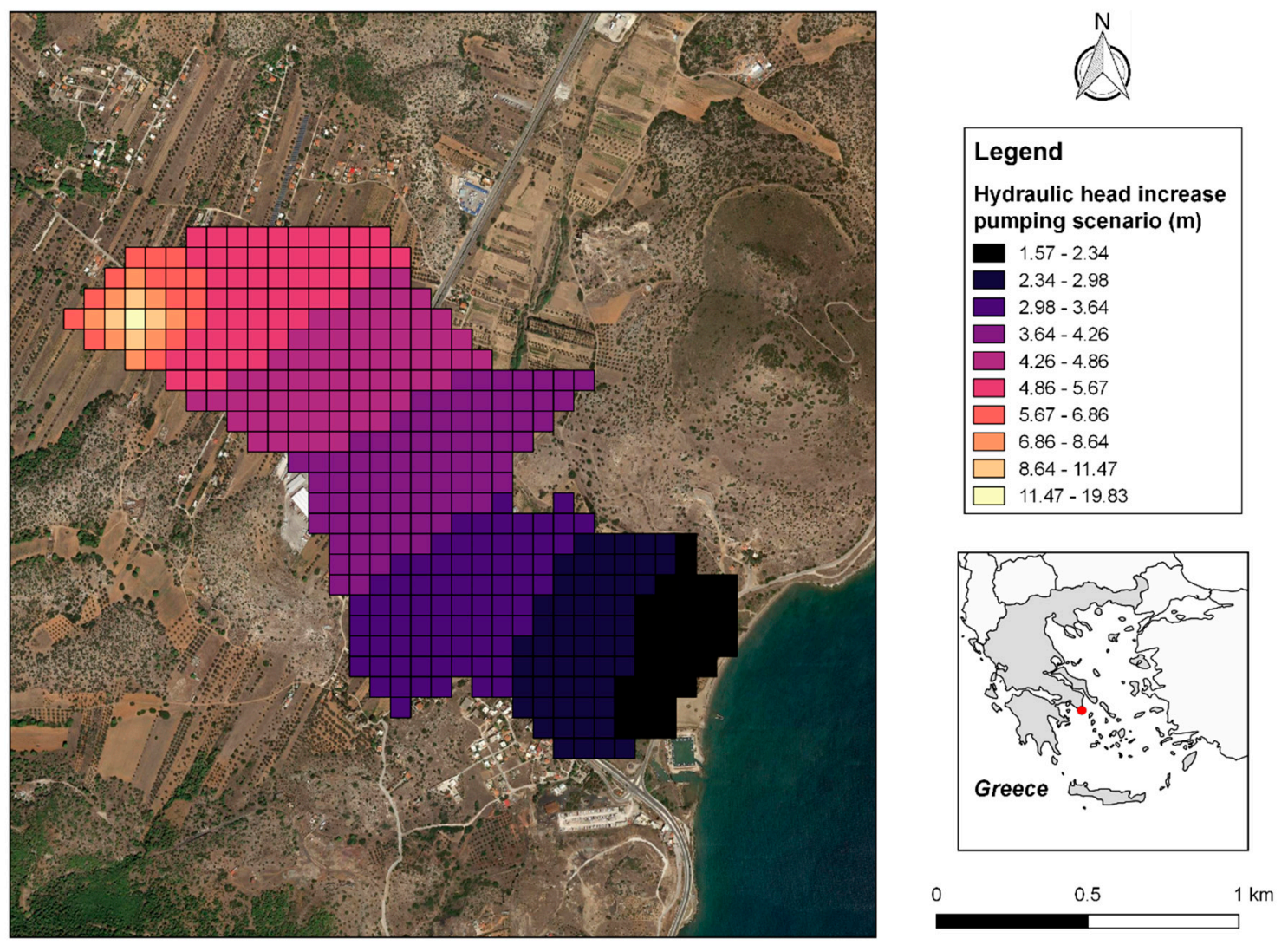

Figure 6. Spatial variation in the groundwater level increase in the case of infiltrating treated wastewater in the Lavrion area.

Model implementation using the FREEWAT platform benefited from the GIS-integration, which made model building faster with respect to other software intended for the same purposes. In 
this regards, specific tools integrated in FREEWAT for pre- and post-processing of time-series data distributed in space were relevant, especially in complex hydrogeological environments like the Lavrion area.

\subsection{Ground- and Surface-Water Interaction}

The topic of ground- and surface-water interaction has been of particular interest in recent decades [50]. Surface water bodies, indeed, are often hydraulically connected to groundwater and the use or pollution of one resource can be of concern for the protection of the other [51,52].

In many cases, groundwater management may benefit from interaction with surface water bodies. As an example, ground- and surface-water interaction may play an important role in arid and semi-arid regions where agriculture represents a major human activity [53,54]. In such cases, GWRM is of paramount importance to adequately plan the conjunctive use of ground- and surface-water. This is being recently assisted also through Managed Aquifer Recharge (MAR) solutions aimed at improving water quality, sustaining water demand during dry periods, and sustaining groundwater-dependent ecosystems [55-57]. This topic was treated at three case studies using FREEWAT in Slovenia, Czech Republic, and Turkey.

\subsubsection{Vrbanski Plato, Slovenia}

The Vrbanski plato aquifer belongs to the Danube river basin and represents the major source of freshwater for 14 municipalities in north-eastern Slovenia. Here, groundwater is hosted in an alluvial aquifer in hydraulic contact with the Drava river [58]. This aquifer has been exploited for 40 years by means of an Induced RiverBank Filtration (IRBF) MAR scheme, consisting of a set of pumping wells along the banks of the Drava river.

The FREEWAT platform was applied to this case study to investigate potential impacts on groundwater quality at the Vrbanski plato pumping station, which is protected by the National Decree on water protection zones, due to the occurrence of polluting activities at the nearby Maribor city. In March 2016, a large spill of heating oil in the Maribor city was detected and, in October 2016, two remediation wells were set in place for a floating oil layer recovery system by dual pump-and-skim technology. These features were modeled to get information about the effects of pumping on the groundwater regime.

Different scenarios of recharge and pumping rates were simulated (Figure 7), to detect potential shifts of the watershed divide, which occurs in the center of Maribor. The direction of the oil spillage was consequently foreseen for each scenario. Results demonstrated that a shift of the watershed divide westwards would occur with average pumping rates at the Vrbanski plato and averaged or increased groundwater recharge, consequently redirecting the oil spillage away from the pumping station of Vrbanski plato. Also, nine months after the occurrence of the contamination event, the contaminant would be fully contained within a local cone of depression.

The use of water resource management tools like FREEWAT has a significant role in the establishment, maintenance and optimization of efficient MAR schemes like that modeled in this case study. The free and open source characteristics of the FREEWAT platform were well appreciated by local stakeholders, especially in terms of database and model portability, as they can maintain and update the developed model for planning and management of the IRBF scheme. 


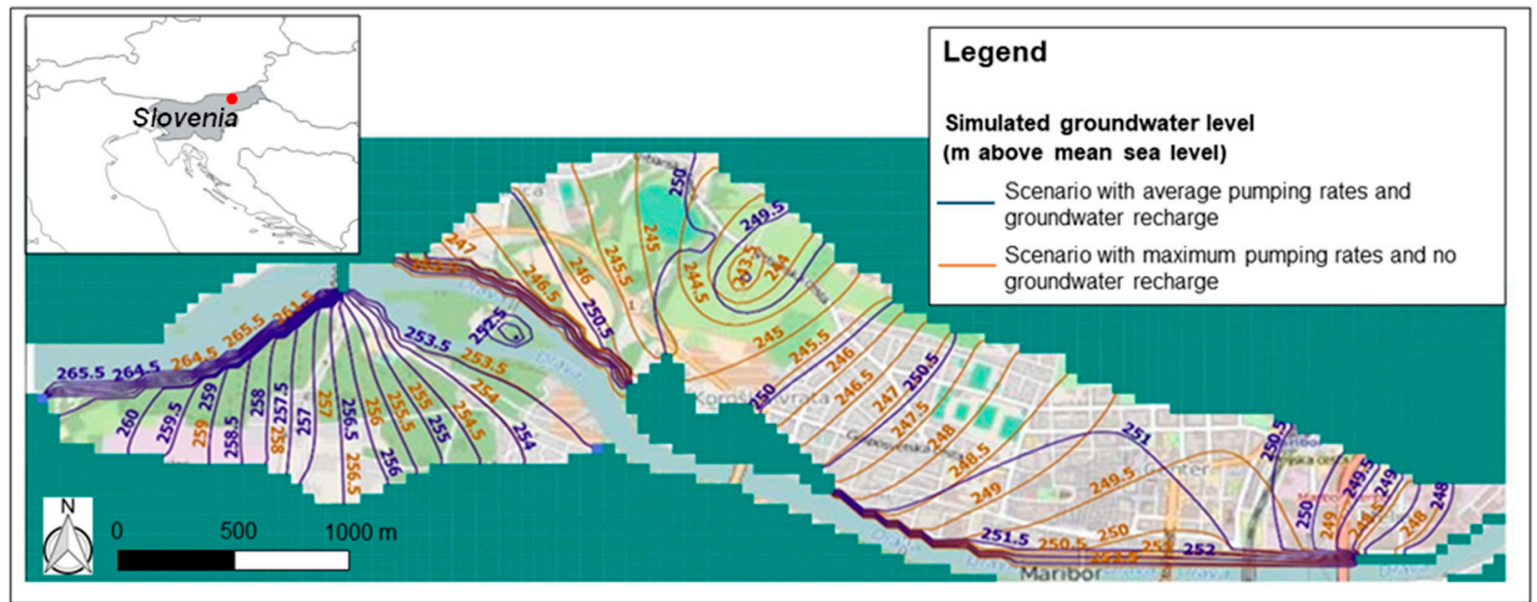

Figure 7. Location of the watershed divide simulated under different scenarios of water management.

\subsubsection{Velké Žernoseky, Czech Republic}

In the Velké Žernoseky area (north-western Czech Republic) ground- and surface-water resources are exploited by a number of stakeholders, causing conflicts. This holds especially true in the drinking water sector and such issue is exacerbated during extreme climate conditions. The entire area, indeed, is regularly endangered by floods. In this framework, the main objectives of this case study were: (i) optimizing water resources management, and (ii) developing tools to provide climate services, i.e., water management measures as foreseen within EU water-related directives and the Czech Water Act.

The site of Velké Žernoseky (Figure 8) extends over a small area of $3 \mathrm{~km}^{2}$, centered on a flooded open pit excavated for gravel mining and nowadays used for recreational purposes. The entire area belongs to protected zones of the nature conservation area of České středohoři (Central Bohemian Uplands). Here, groundwater is hosted in a multi-layer aquifer in hydraulic contact with the open pit and with the Elbe river [59].
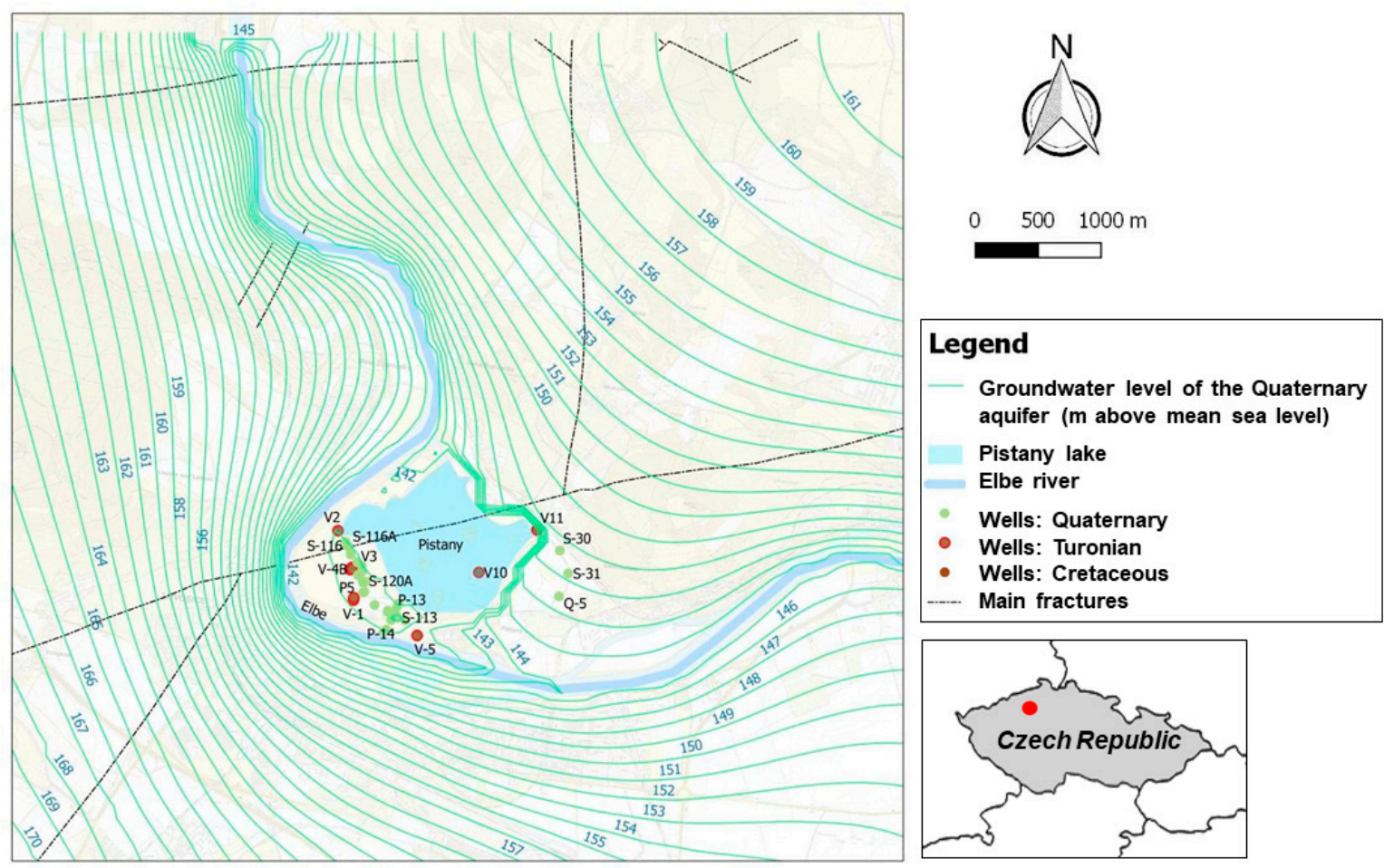

Figure 8. Simulated groundwater level in the model area. 
After simulating the groundwater regime under natural conditions (e.g., with no abstractions), the FREEWAT platform was applied to simulate several scenarios of climate conditions and groundwater pumping. The hydrometric level of the Elbe river was modified to simulate dry climate conditions and flood events. Results demonstrated that abstraction rates not higher than $110 \mathrm{l} / \mathrm{s}$ in the shallow aquifer and $25 \mathrm{l} / \mathrm{s}$ in the deep one would have a limited impact on the groundwater flow regime, if the hydrometric level of the Elbe river stands around $141 \mathrm{~m}$ above mean sea level.

The developed model allowed a feasible management setup for groundwater uptake by the local waterworks company to be depicted, thus setting the stage for improving management practices of ground- and surface-water resources and flood risk. During this modeling experience, the completeness of the FREEWAT platform with respect to pre- and post-processing tools and tools for model implementation was considered a keypoint. In particular, the integration within the QGIS environment was particularly convenient, as this allowed to save time during input data processing and model construction.

\subsubsection{Palas Basin, Turkey}

Palas basin is a semi-arid, closed basin located in the Central Anatolia region of Turkey. It hosts a lacustrine ecosystem, the Tuzla lake, which has a conservation status (Nature Conservation Area), due to its biodiversity value. In recent years, decreases in water levels have been detected at Tuzla lake, which is fed by groundwater, precipitation and surface water flows from the adjoining hills and the Değirmen stream.

In this case study, the FREEWAT platform was applied to develop a groundwater flow model, as a first attempt to analyze the relationship between ground- and surface-water and to analyze the effects of agricultural water use on the hydrology of the Tuzla lake [60]. Different groundwater abstraction scenarios were run, to understand how aquifer exploitation for irrigation purposes affected the lake hydrology. Water flows to the Tuzla lake were found to be significantly related to pumping rates. As an example, a complete stop of groundwater pumping would increase river drainage by $0.9 \mathrm{Mm}^{3} /$ year and discharge to the Tuzla lake by $0.6 \mathrm{Mm}^{3} /$ year. Furthermore, an increase of about $0.5 \mathrm{~m}$ of the average lake level would be recorded. On the other hand, increasing groundwater pumping by $50 \%$ with respect to the current situation (Figure 9) would make the river drainage to decrease by $0.4 \mathrm{Mm}^{3} /$ year and the discharge to the Tuzla lake to decrease by $0.3 \mathrm{Mm}^{3} /$ year. Groundwater level would go down significantly in the southern part of the basin, where pumping wells are densely distributed. The average lake stage would drop about $0.3 \mathrm{~m}$ lower than the current one.

FREEWAT proved to be an efficient tool for developing an integrated understanding of groundand surface-water management problems at the basin scale. This is mostly because it relies on the application of well-known and widely used codes for modeling ground- and surface-water interaction, complemented by data analysis and visualization tools in a unique platform equipped with a user-friendly interface in a GIS framework. 


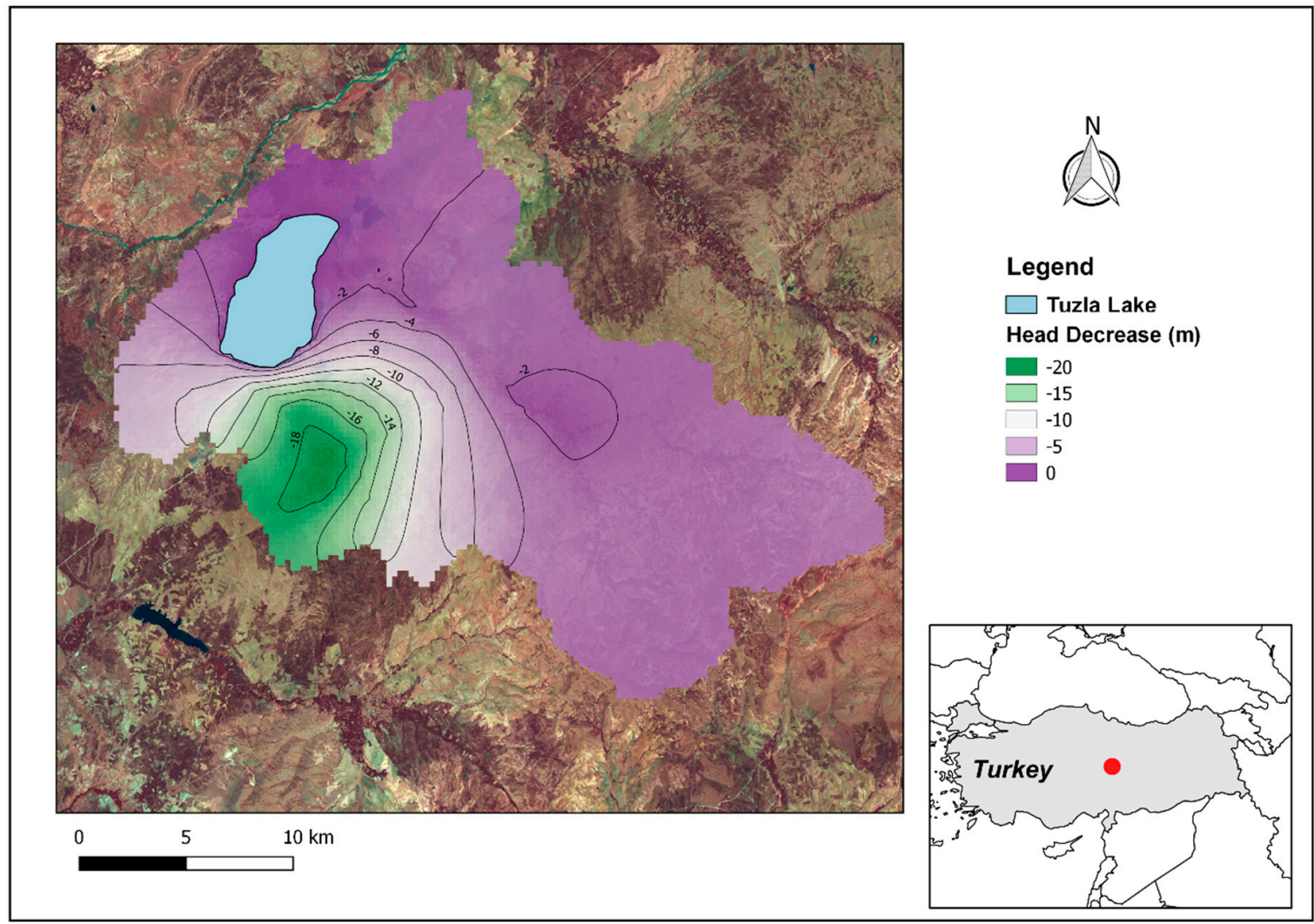

Figure 9. Difference between the hydraulic head simulated under current exploitation conditions and the hydraulic head simulated assuming an increase of pumping rates by $50 \%$.

\subsection{Climate Change}

The potential impacts of climate change on groundwater resources have been widely assessed at the global level (e.g., [61,62]), or at the basin scale connecting climate and groundwater flow models (e.g., [63]). These impacts were evaluated at two case studies using FREEWAT in Germany and Romania.

\subsubsection{Bremerhaven District, Germany}

The city of Bremerhaven is located east of the river Weser estuary, in north-western Germany, facing the North Sea coast. The area lies within the 4_2501 "untere Weser Lockergestein rechts" groundwater body, which is being extensively monitored to control its equilibrium under climate-driven stress conditions, as required by the WFD, in order to maintain its current qualitative and quantitative status. Such equilibrium is threatened by seawater intrusion phenomena, as a consequence of sea-level rise and changes in groundwater recharge.

To support the assessment of the hydrogeological equilibrium in the Bremerhaven district, a groundwater flow model was implemented applying the FREEWAT platform [64]. A first steady-state stress model, from 1981 to 2010, was run, followed by three transient models, each of them 30 years long, until 2100. Decrease of groundwater recharge in combination with sea-level rise was simulated, in order to make forecasts about potential effects of climate change on the aquifer system. Model outcomes demonstrate that groundwater level decline up to $2 \mathrm{~m}$ would occur by the end of the century (Figure 10), while seawater intrusion would affect the commercial and industrial areas close to the coast. As a further result, some measures of groundwater management were assessed, according to suggestions provided by local stakeholders. Among these, rainwater harvesting during extreme rainfall events for infiltration, and the shift of abstraction wells far from the coast were simulated. The 
model developed thus represents an important forecasting tool for groundwater management in areas particularly affected by climate-driven risks.

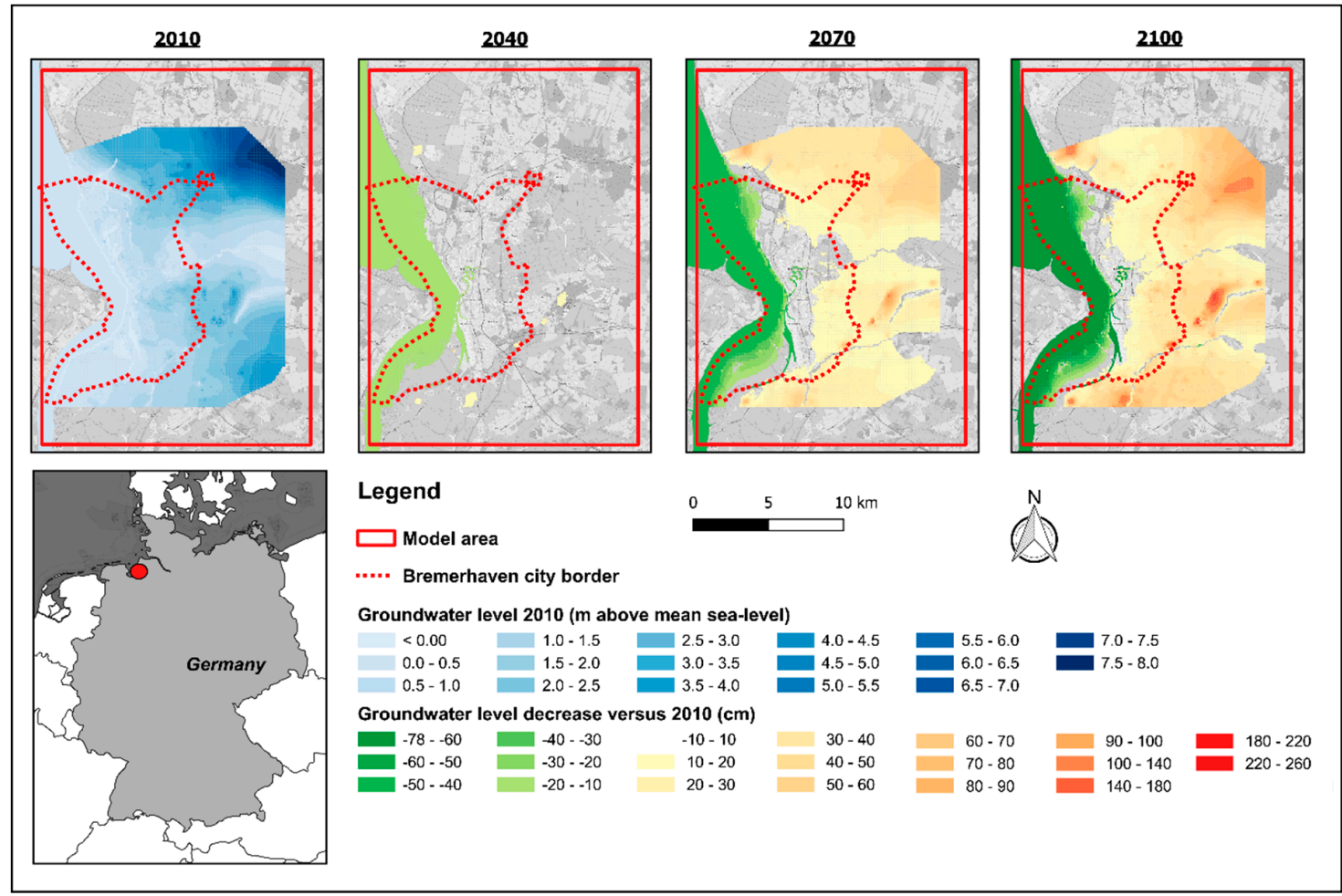

Figure 10. On the left side, groundwater level simulated as a result of the first steady-state model (1981-2010). The next three maps show the groundwater level decrease due to sea-level rise and decreasing recharge in years 2040, 2070 and 2100.

The relevance of these outcomes in the described case study makes the FREEWAT platform a suitable tool and a potential standard software for water authorities. In this sense, the availability of a wide set of post-processing tools, the possibility to use web services (e.g., climate projection models), and to appreciate the spatial variability of climate change impacts in a GIS environment are keypoints in the reporting phase of the evaluation procedure.

\subsubsection{Banat Plain, Romania}

The Banat alluvial plain is located in western Romania, between Mures and Timis rivers. Here, groundwater is hosted in sandy-gravelly quaternary deposits, which delineate a multi-layer aquifer system with a shallow phreatic aquifer and a deeper body [65]. The latter represents a major source of freshwater for human needs, mostly related to drinking water supply and the industrial sector. By contrast, the shallow aquifer is currently used for domestic purposes only.

Despite currently being in good quantitative status, the deep aquifer of the Banat plain is potentially at risk of overexploitation, in view of increasing water demand and in relation to climate change projections for the next decades. This makes urgent the need to assess groundwater management strategies, and to increase sustainable use of groundwater resources. In this framework, a numerical model of the shallow aquifer within the Banat plain was developed by applying the FREEWAT platform, in order to infer groundwater availability from shallow/surface sources of water. The main goals of this modeling activity were: (i) to improve the existing knowledge of groundwater bodies within the studied area, (ii) to forecast the evolution of the shallow aquifer in response to different stresses related to climate change and variable groundwater exploitation regimes. 
Model results allowed the major components of the hydrologic budget to be quantified for different scenarios of climate change and groundwater exploitation. Four scenarios were developed: (1) decrease of precipitation by $4.2 \%$ (climate projection to 2021; Figure 11, left); (2) decrease of precipitation by $5.3 \%$ (climate projection to 2071; Figure 11, right); (3) increase of groundwater pumping by 50\%; (4) deployment of pumping wells in an area where the Bega river recharges the aquifer. The first three scenarios resulted in an overall decrease of the piezometric head, up to more than $0.7 \mathrm{~m}$ (scenario 1 ; Figure 11, left), $1.7 \mathrm{~m}$ (scenario 2; Figure 11, right), and $2.0 \mathrm{~m}$ (scenario 3). Scenario 4 demonstrated to be an optimal compromise to meet water demand without affecting groundwater availability to a relevant extent.

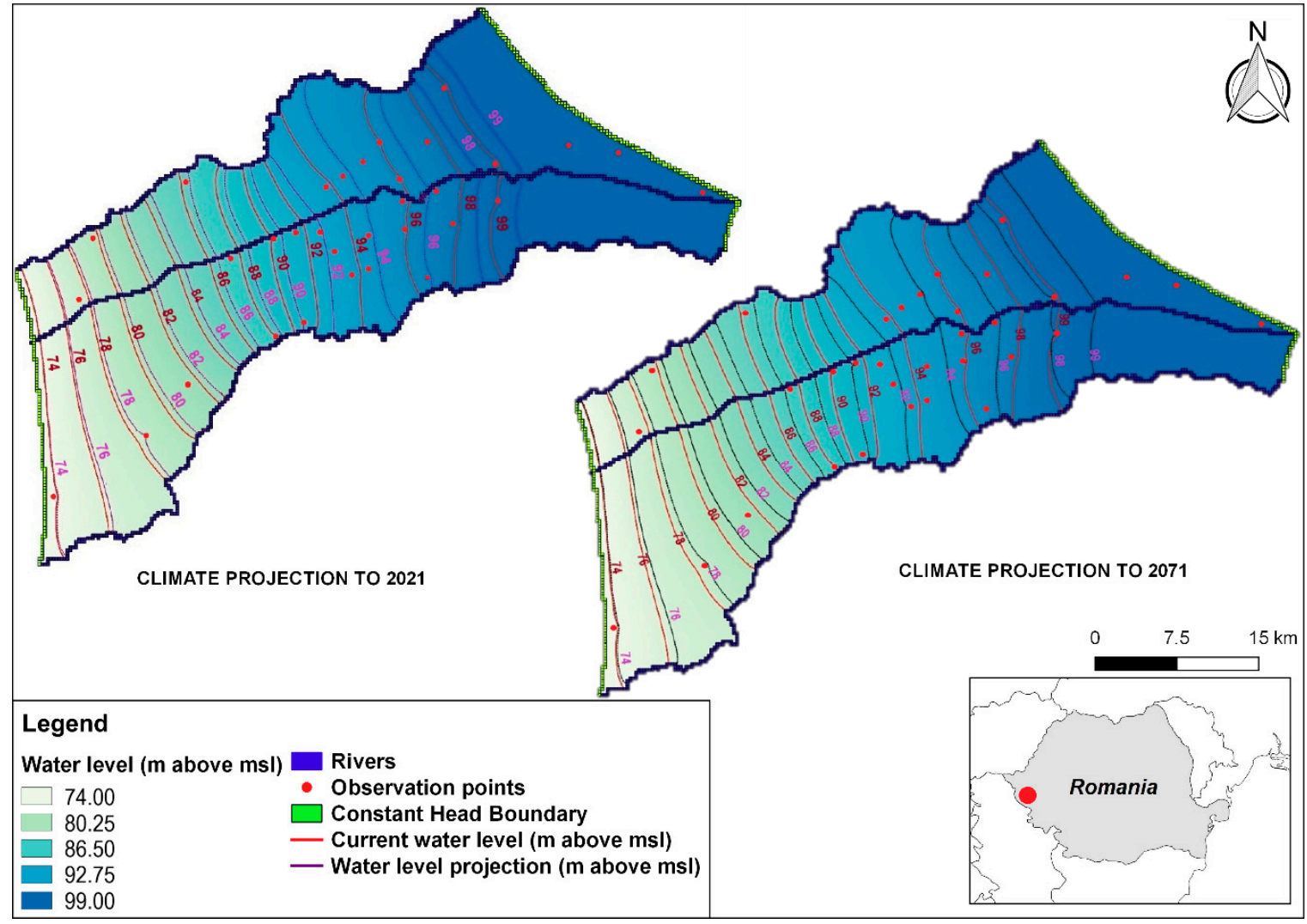

Figure 11. Geographical framework of the study area, boundaries of the major groundwater bodies and simulated groundwater level.

A major strength that emerged from this application was the completeness of the FREEWAT platform with respect to the possibility to simulate several components of the hydrological cycle (i.e., ground- and surface-water interaction in a framework of climate change and human exploitation). Of outmost importance in this framework is the availability of tools, like OAT, for the analysis of sensors data for a comprehensive understanding of the processes involved. In this regards, integration of the FREEWAT suite in a GIS environment was a relevant aspect for investigating the spatial variability of the hydrogeological features included.

\subsection{Management of Transboundary Aquifers}

Groundwater management is a complex task, which requires effective communication among scientists, professionals and water managers. In case of transboundary aquifers (TBAs), this is even more complex, because groundwater resources are subject to different jurisdictions, socio-economic and political settings [66]. The most recent map of TBAs of the world [67] reports 592 TBAs among the five continents, including transboundary groundwater bodies as defined in the WFD. Despite 
their importance, management of TBAs at the international level often receives poor attention. This is mostly due to difficulties to undertake shared cooperation among policy-makers belonging to the countries involved [68]. As an example, in Africa, only seven aquifers, out of more than 70, are subject to agreements on joint research, monitoring and governance [69]. FREEWAT capabilities were tested at two case studies to deal with this theme in Switzerland/Italy, and Namibia/Botswana/South Africa.

\subsubsection{Lugano Lake Watershed, Switzerland/Italy}

The Lugano lake watershed, being a transboundary watershed between Italy and Switzerland, is subject to Swiss, and European regulations. As such, besides the EU WFD, its status is regulated by Swiss federal law on water protection and the corresponding ordinance, which regulate water use to ensure integrated water protection from quantitative and qualitative points of view, and to define the ecological objectives of water-related ecosystems.

The main concern in the watershed is the eutrophication of the Lugano lake, due to relationships with groundwater. Currently, the concentration of phosphorous exceeds threshold values imposed by regulations (values determined in 2014 were worth 21 tons in the northern basin and 34 tons in the southern basin, against 18 tons and 22 tons, respectively, as threshold values [70]). It is thus important to better understand the phosphorous contribution from groundwater, in order to eventually define policies and management strategies, so as to reduce this contribution term. The Lugano lake watershed includes five main aquifers, hydraulically connected one to each other by the lake itself. Two of them, Porto Ceresio and Porlezza, are located in Italy, while the remaining three, Lugano, Agno and Mendrisio, are located in Switzerland. The hydrologic system is very dynamic and largely depends on surface water flows, contributed by the Lugano lake and by the streams and rivers network within each sub-basin. The application of the FREEWAT platform allowed the interaction between ground- and surface-water to be investigated [71]. OAT was extensively used throughout the modelling phase for data pre-processing to implement boundary conditions and source/sink terms. Specifically, time-series data of lake stage, rivers' stage, precipitation, temperature and head observations were managed through OAT to resample sensor data according to the time discretization of the model.

Model results highlighted that the piezometric head distribution within each aquifer is highly dependent on the variations of stage and volume of the Lugano lake. Also, the simulated exchange rates between groundwater and the lake $\left(1.0 \mathrm{~m}^{3} /\right.$ day to $4.0 \mathrm{~m}^{3} /$ day; Figure $\left.12 \mathrm{a}\right)$ match quite closely the time evolution of the lake and rivers' stages (Figure 12b), although the lake seepage component stays comparatively low and constant throughout the year (less than $0.5 \mathrm{~m}^{3} /$ day).

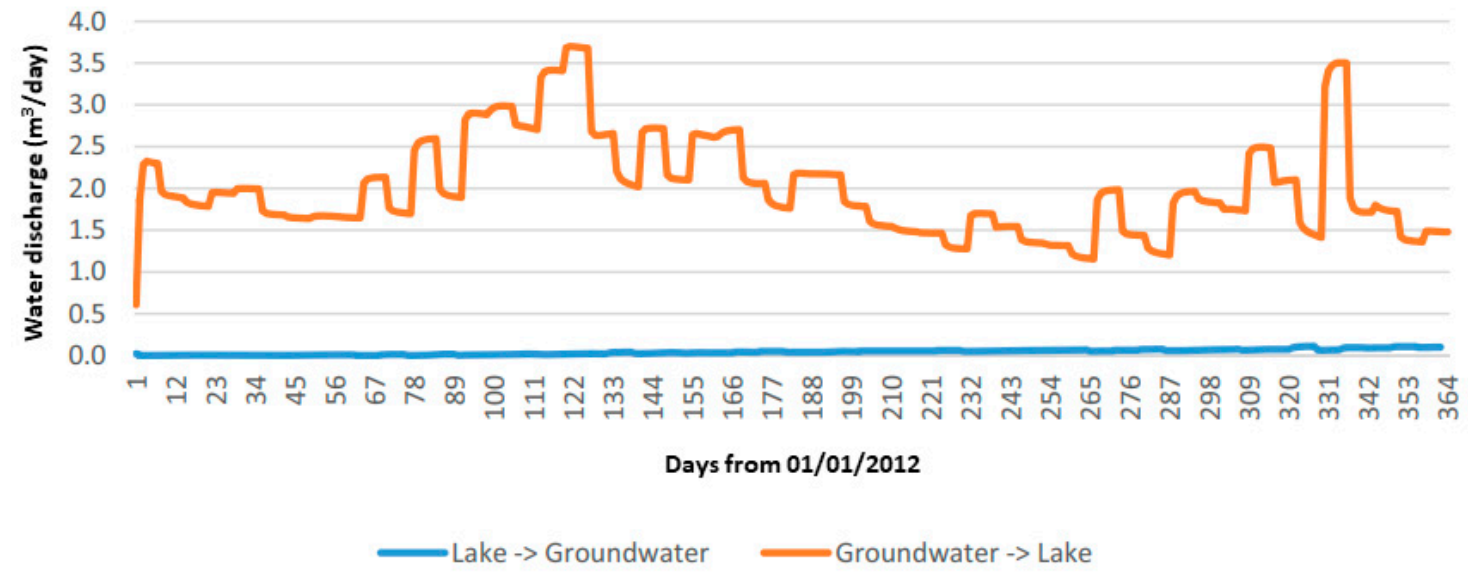

(a)

Figure 12. Cont. 


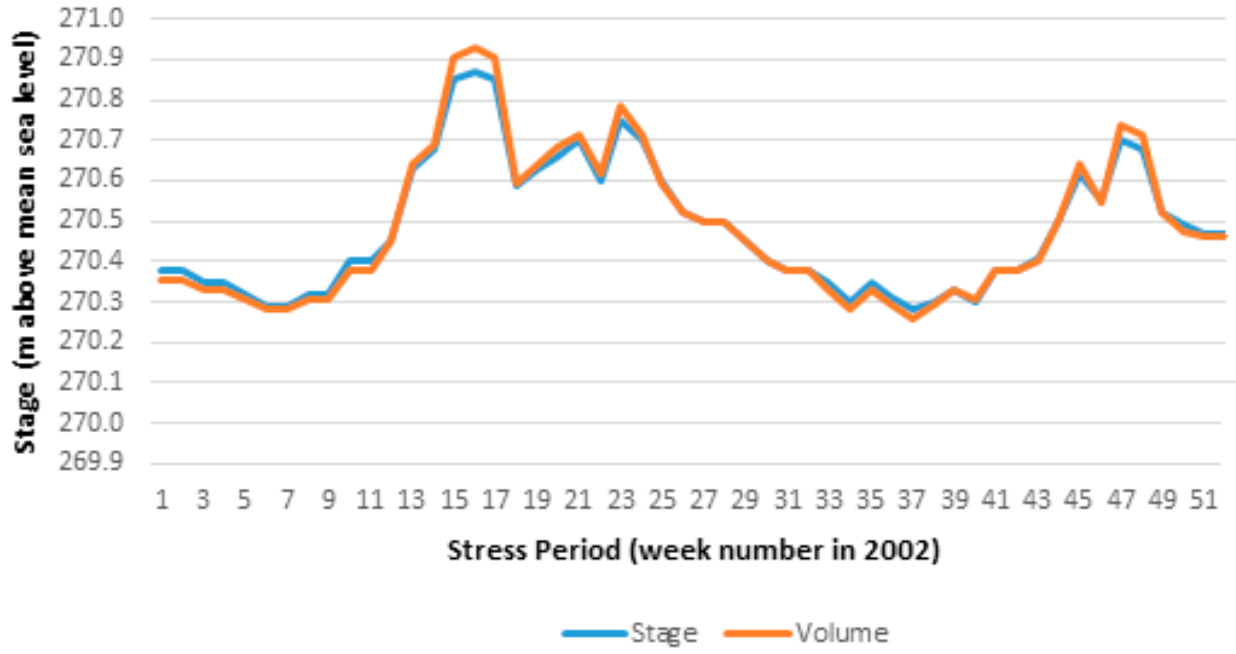

(b)

Figure 12. (a) Modeled flow rates exchange between the Veddeggio aquifer and the lake; (b) simulated lake stage and volume over the simulation length.

This is the first modeling experience related to the Lugano lake watershed and it sets the stage for further investigations. The most recognized benefit of using FREEWAT for this case study resided in its ability to easily share the model and related data among stakeholders, which led to maximizing the reuse and optimizing the resources by sequential improvements of the model with new data and scenarios.

\subsubsection{Stampriet Transboundary Aquifer System, Namibia/Botswana/South Africa}

The Stampriet Transboundary Aquifer System (STAS) is among the largest TBAs worldwide [72]. It covers a large arid region stretching from central Namibia into western Botswana and South Africa's Northern Cape Province. Given the climatic conditions of the area and the lack of a permanent surface water network, groundwater stored in the STAS represents the only source of freshwater in a region which is sparsely populated (nearly 50,000 inhabitants over an area of about $87,000 \mathrm{~km}^{2}$ ). The management of the STAS is not regulated within a governance process shared among the involved countries. Transboundary cooperation is needed to harmonize interventions run at national levels. In this framework, the three countries are willing to cooperate for developing responses to current and future development of the STAS. This process is being supported by UNESCO-IHP (United Nations Educational, Scientific and Cultural Organization-International Hydrological Programme) through the involvement of the three governments in projects dealing with the assessment of the current status of the STAS. The final purpose of this approach consists in setting up a Multi-Country Co-operation Mechanism for the governance and management of the STAS, the first example of this kind in the Southern African Development Community region and one of the few worldwide.

The STAS is part of a sedimentary basin in which three major aquifer systems may be recognized. Such aquifers are separated by shale layers which act as aquitards. The conceptual model of the aquifer system is reasonably understood, but quantification is still limited due to data scarcity. The FREEWAT model took steps from a previous model [73] concerning only the Namibian part of the STAS area. Such model was extended to Botswana and South Africa exploiting results of the GGRETA project [74]. Automatic inverse calibration was run over the most sensitive parameters. Figure 13 shows the spatial distribution of residuals (observed minus simulated hydraulic head values) calculated after model calibration: red dots are located in areas where the model over-estimates the observed values, while blue dots refer to model under-estimates. Tailored residual map plotting is an example of how GIS is one of the best choice for result presentation. 


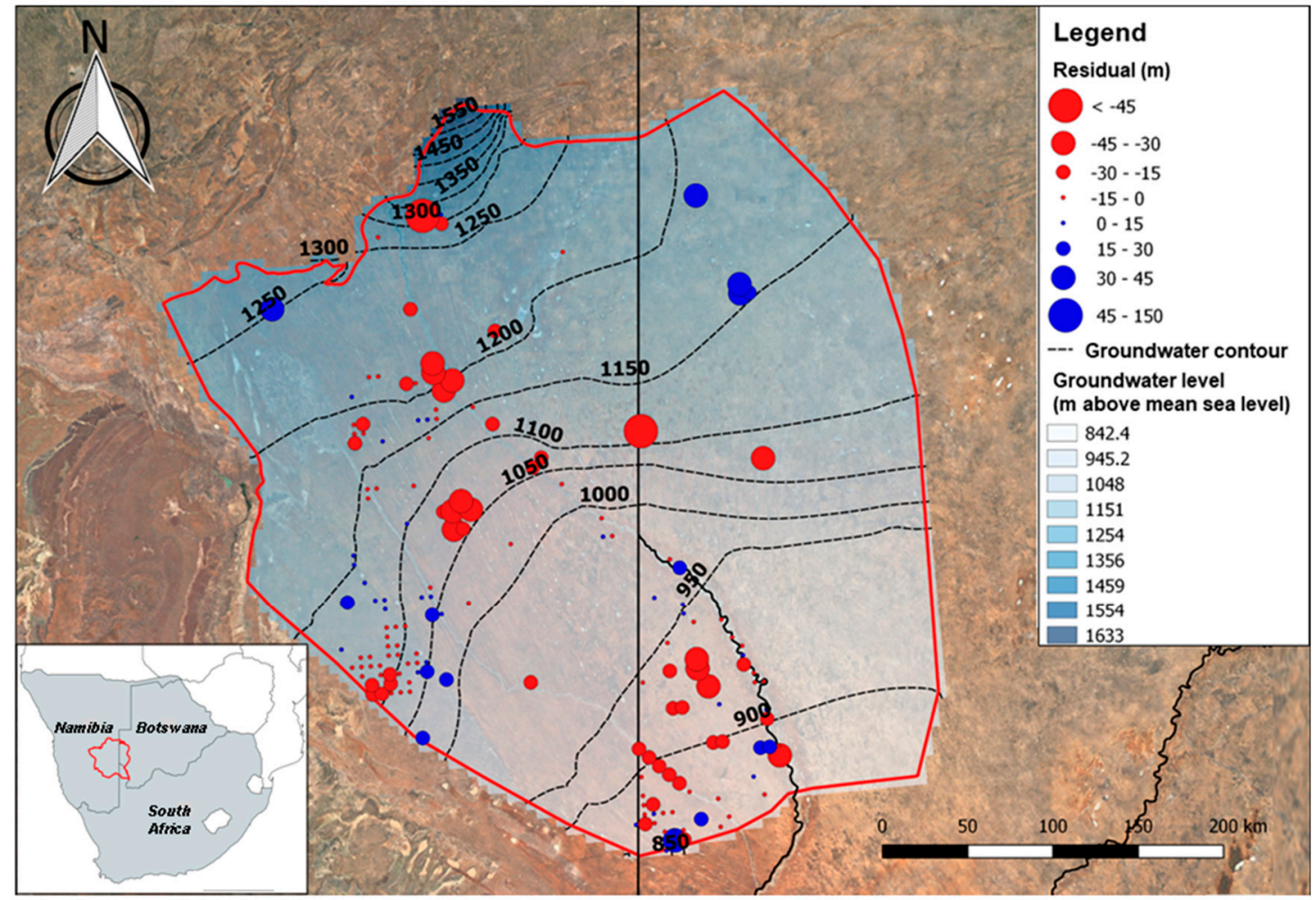

Figure 13. Map of residuals calculated after model automatic calibration.

The developed model, along with capacity building and participatory approach (e.g., focus groups) activities run during the FREEWAT project, allowed existing knowledge gaps, mostly due to data scarcity, to be revealed. These are to be addressed in the framework of a joint upgrading and updating of the existing database. As such, this model represents a first tool to foster transition from project-driven cooperation to institutionalized cooperation among the STAS countries. The possibility to accomplish this task relying on free-licensed software tools, like FREEWAT, is relevant in low-income countries, and the portability characteristics of the developed models are essential in a cooperation framework.

\subsection{Rural Water Management and Protection of Groundwater-Dependent Ecosystems}

About $38 \%$ of global irrigated areas rely on groundwater [75]. This resulted in a concerning increase of groundwater abstraction for irrigation purposes (10-fold increase over the past 50 years) [76]. However, groundwater management in rural areas also concerns land reclamation and drainage $[77,78]$ and the protection of groundwater-dependent ecosystems [79,80]. FREEWAT was applied at three case studies to deal with this theme in Ukraine, Italy, and Estonia.

\subsubsection{Bakumivka River Catchment, Ukraine}

The forest-steppe environmental zone in northern Ukraine is characterized by uneven distribution of precipitation and alternation of dry and wet seasons. That is why agriculture in such zone requires drainage-irrigation systems, allowing both irrigation and drainage while needed. In the Bakumivka river catchment, the drainage-irrigation system consists of an extensive network of secondary channels, whose main function is to detain or drain water into the Bakumivka river. The drainage-irrigation system has seriously affected the water regime of this catchment. This caused in turn several environmental issues (e.g., the occurrence of peat fires, dehumidification, wind erosion, loss of biodiversity), which trigger the need for a synergic management of water and land use [81]. 
The main objective of FREEWAT application to the Bakumivka river catchment was to assess the optimal spatial distribution of water use, by taking into account changes in the land cover pattern [81]. To this aim, three scenarios allowed to compare different spatial patterns of land cover and water distribution. In the first scenario ("traditional"), crops and land-cover patterns typical of the region in the recent five years were simulated. The second scenario ("market-oriented") was based on the assumption that the most profitable crops (corn, sunflower and rapeseed) occupy about $70 \%$ of the arable lands. The third scenario ("environmentally sounding") considered removing rapeseed and sunflower, reducing areas cropped with corn and enlarging areas with perennial herbs, and creating eco-corridors and ecotones.

For each scenario, the difference between the simulated hydraulic head and the optimal one for each land cover class was evaluated, in order to identify areas where water availability would be optimal, insufficient or excessive for a specific crop type (Figure 14). Model results demonstrated that changing the land-cover pattern could be effective in reducing water supply to the farms, however it would not solve the problem of water logging within the flood plains, as well as the problem of drying during the summer season in sandy-loamy soils.
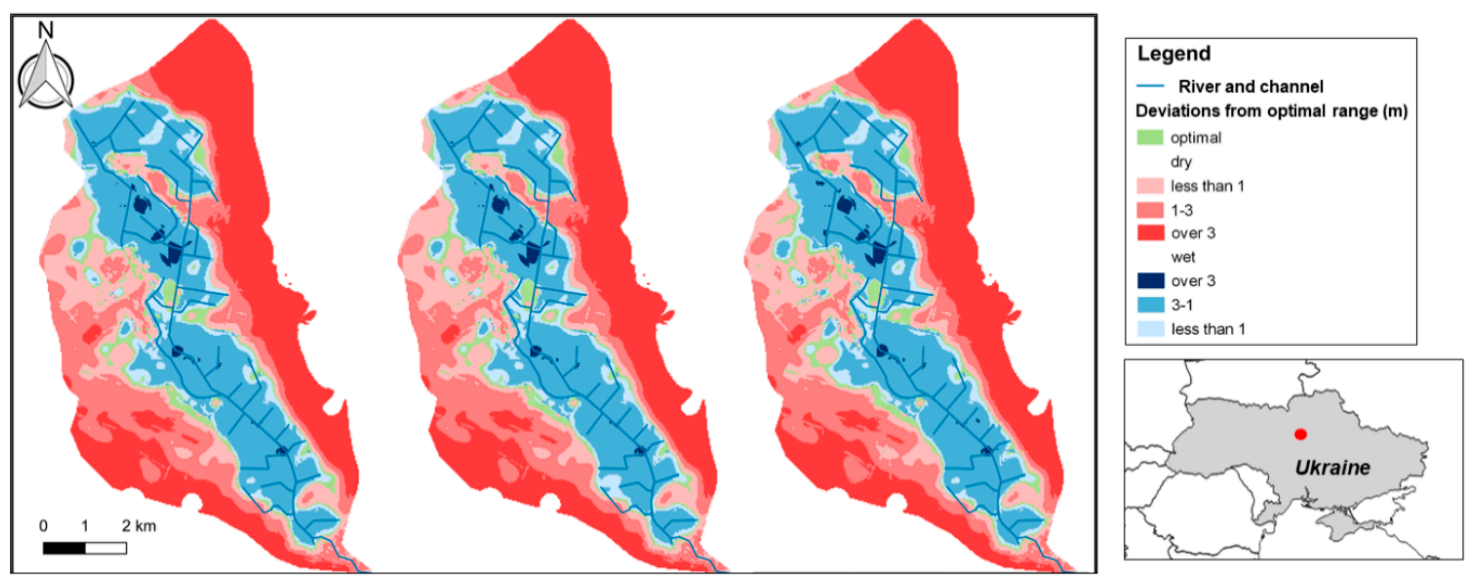

Figure 14. Difference between the simulated hydraulic head and the optimal one for different scenarios. From left to right: traditional, market-oriented, and environmentally sounding scenarios.

Management of spatial data was an onerous task during this modeling experience. In this regards, the implementation of modeling scenarios was quite straightforward thanks to the integration of FREEWAT tools for effective data management within a GIS environment, complemented by the adoption of SpatiaLite as a database management system.

\subsubsection{Massaciuccoli Lake Basin, Italy}

The Massaciuccoli lake is located within a coastal lacustrine and marshy area in central Italy. Such area has been largely drained since 1930 for agricultural production [82]. This triggered a series of environmental issues, among which land subsidence, which left the lake perched with respect to the low drained area. This required the construction of embankment structures and a system of drainage channels and dewatering pumps to prevent waterlogging and flooding [83]. As a result, the lacustrine ecosystem is undergoing salinization and eutrophication, exacerbated by severe water stress occurring during dry summer seasons. All these issues are exacerbated in the southernmost part of the Massaciuccoli lake basin [84], where new land and water management strategies are needed.

In this case, the FREEWAT application aimed at testing strategies for redesigning an area of the reclaimed land by means of controlled rewetting, reducing the drained thickness, for alternative cropping strategies (e.g., for paludiculture purposes). Initial model results show that interactions between ground- and surface-water reflect in complex water dynamics, with a strong seasonality [83]. Simulations were then run using FREEWAT in order to estimate the extension of the rewetted area, 
based on changing the elevation of the water stage in drains. Scenarios were explored by raising drains' elevation by $0.2 \mathrm{~m}$ (scenario 1, $3.2 \mathrm{~m}$ below mean sea level) and $0.4 \mathrm{~m}$ (scenario 2, $3 \mathrm{~m}$ below mean sea level) with respect to the current stage ( $3.4 \mathrm{~m}$ below mean sea level), in order to induce controlled rewetting of the drained areas. Results were evaluated during the recharge season and at the end of the dry summer season. In the case of scenario 1, the rewetted areas would extend up to 280 ha in August 2008 and up to 215 ha in April 2009 (Figure 15a,c). In the case of scenario 2, the rewetted areas would extend up to 715 ha in August 2008 and up to 450 ha in April 2009 (Figure 15b,d).

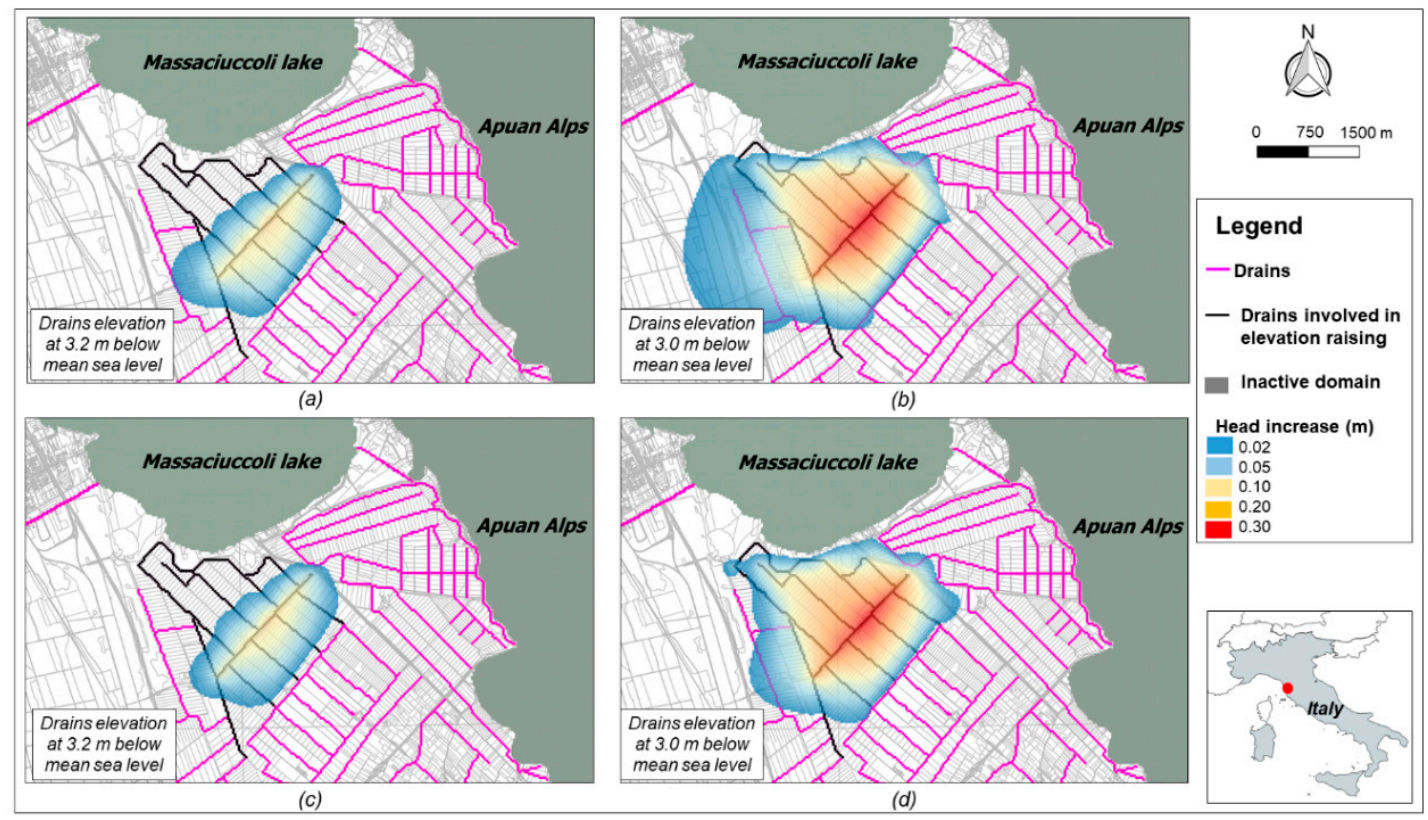

Figure 15. Head increase after raising drains' elevation: (a) scenario 1, end of August 2008; (b) scenario 2, end of August 2008; (c) scenario 1, end of April 2009; (d) scenario 2, end of April 2009.

This application highlighted the importance of managing and processing in the same environment a large amount of spatial data for modelling purposes. This holds especially true during the pre-processing phase of input data preparation, given the fine discretization of the model in space (grid cell length side of $25 \mathrm{~m}$ ) and time. Results of the simulation were shown in public meetings with authorities, demonstrating the importance of providing visual results of geo-engineering actions on the environment. Visualization may be enhanced by using geospatial tools.

\subsubsection{Selisoo Bog, Estonia}

The Selisoo bog is a swampy area located in north-eastern Estonia, within the Ordovician Ida-Viru oil-shale basin groundwater body. It includes a wetland belonging to the Natura 2000 network. The oil-shale mining activities take place besides the eastern boundary of the bog, at a depth of about $60 \mathrm{~m}$ below the ground surface. In places, the mining also extends below the bog. Due to the mining activities, about $200,000 \mathrm{~m}^{3}$ of water are drained daily from the aquifer system and collected into the surface water network. This results in a decrease of the groundwater levels in the bedrock aquifer and also in the Quaternary sediments below the bog, influencing the water regime in the whole area and, thus, endangering the overall functioning of the wetland water budget [85].

Within this framework, a modelling approach was adopted to assess the effects of the underground mining activities on the hydrological cycle of the study area and to test the results' dependence on model structure. The modelling approach consisted in representing the hydrodynamic behavior in the study area by means of six alternative flow models. In one, the mining area was not simulated. In other models, different ways of representation of mining processes were simulated, by implementing different boundary conditions. Results of the alternative models were compared with statistical 
methods, in order to devise the most accurate representation of the hydrological system. The automatic calibration of the alternative models clarified that the upper aquitards in the hydrostratigraphic setup would play a key role in the hydrodynamic behavior of the system. Figure 16 reports the water budgets simulated for the six alternative models.

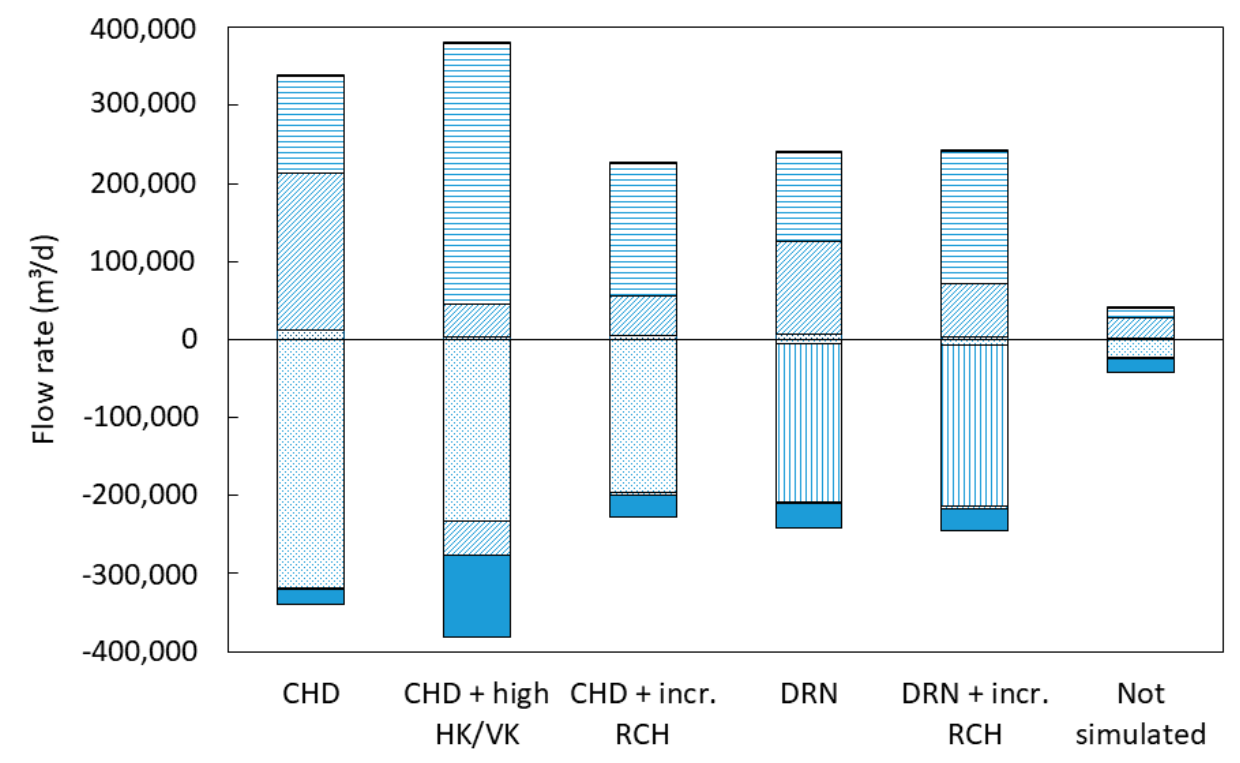

$\square$ Stream Leakage $⿴ 囗 ⿱ 一 一)$ Recharge $\square$ Head Dependent Boundaries $⿴$ Drains $\square$ Constant Head

(a)

\begin{tabular}{|c|c|}
\hline $\begin{array}{l}\text { Acronym for the } \\
\text { alternative model }\end{array}$ & Description \\
\hline $\mathrm{CHD}$ & $\begin{array}{l}\text { Mining area simulated as Constant Head Boundary (the elevation equals the basis of the mining } \\
\text { layer) }\end{array}$ \\
\hline $\begin{array}{l}\text { CHD + high } \\
\text { HK/VK }\end{array}$ & $\begin{array}{l}\text { Mining area simulated as Constant Head Boundary (the elevation equals the basis of the mining } \\
\text { layer) } \\
\text { The mining area has horizontal and vertical hydraulic conductivities (HK and VK) equal to } 1000 \\
\text { m/day }\end{array}$ \\
\hline $\mathrm{CHD}+$ incr. $\mathrm{RCH}$ & $\begin{array}{l}\text { Mining area simulated as Constant Head Boundary (the elevation equals the basis of the mining } \\
\text { layer) } \\
\text { Applied an increased recharge of } 0.0008 \mathrm{~m} / \text { day in the mining area }\end{array}$ \\
\hline DRN & $\begin{array}{l}\text { Mining area simulated as a Drain (conductance equal to } 100 \mathrm{~m}^{2} / \text { day; the drain elevation equals the } \\
\text { basis of the mining layer) }\end{array}$ \\
\hline $\mathrm{DRN}+$ incr. $\mathrm{RCH}$ & $\begin{array}{l}\text { Mining area simulated as a Drain (conductance equal to } 100 \mathrm{~m}^{2} / \text { day; the drain elevation equals the } \\
\text { basis of the mining layer) } \\
\text { Applied an increased recharge of } 0.0008 \mathrm{~m} / \text { day in the mining area }\end{array}$ \\
\hline Not simulated & Mining area not simulated \\
\hline
\end{tabular}

(b)

Figure 16. (a) Groundwater budget terms simulated for the six alternative models (each alternative model is shown on the $\mathrm{x}$ axis); (b) description of each alternative model.

The most appropriate model represents a basis to make predictions on the influence of mining activities on groundwater flow. It could be used to test the effectiveness of mitigation measures foreseen within the WFD and Habitats Directive [86]. 
The integration of pre- and post-processing tools and tools for model implementation in a unique GIS-based platform particularly favored the implementation of the six alternative models, allowing different versions to be built using the same dataset, hence avoiding data redundancy. This characteristic of the FREEWAT platform allows the modeler to set up the modeling workflow, without the need for any additional software.

\section{Discussion}

Besides what was mentioned in the Introduction section, the application of the QGIS-integrated FREEWAT platform at the 13 case studies highlighted the benefits of the approach here presented. A further set of case studies may be found in Rossetto et al. [17], Criollo et al. [19], Cannata and Neumann [25], Perdikaki et al. [87], Koltsida and Kallioras [88], and a complete list of FREEWAT-related peer-reviewed papers is available at the web address http://www.freewat.eu/peer-reviewed-papers.

The following keypoints may be inferred.

1. The implementation of all the data in a single spatial database linked to numerical model codes facilitates model construction and a dynamic representation of hydrological systems. In this view, new data gathering allows populating the built spatial database to verify the quality of the dataset and, while providing new information, this (i) improves the conceptual model under test to constrain the simulated scenarios, and (ii) optimizes the resources by sequential improvements of the models with new data and scenarios. Different model versions may also be easily built, while maintaining the same dataset, avoiding data redundancy.

2. The adoption of SpatiaLite as a relational spatial database is considered effective for facilitating the portability of models and datasets to end users (e.g., public authorities, water managers and policy-makers). In fact, once the model is produced, it can be easily shared with all the other parties interested in the management of the groundwater resource, thus allowing the possibility for all the stakeholders to analyse directly the model (and not only reports), without bearing the cost of proprietary software licences. Model portability also simplifies maintenance and update of the developed model, maximizing the reuse of the work done. Relying on robust free-licensed software, like FREEWAT, is relevant in low-income countries. The portability characteristics of the developed models are essential in a cooperation framework, especially when dealing with (public) water authorities.

3. Furthermore, the single spatial database for groundwater resource analysis provides opportunities for the users to harmonize large amount of data on the aquifer system under investigation and to create, as secondary outcome, a shared knowledge about the spatial features of the groundwater resource in the study area. The approach may also favor the exploitation of existing spatial datasets (i.e., land use, well catalogues, etc.), which are nowadays often produced for planning purposes, but whose information content is seldom fully exploited.

4. Integration in QGIS results in the possibility to use QGIS plugins for raster/vector analysis, data pre-processing and post-processing of model results in an effective way and within a unique environment. This implies no need for supplementary software for processing input data and analyzing output results, making easier, i.e., map preparation, contouring, raster data analysis.

5. The FREEWAT approach, linking the spatial dataset directly to the numerical model implementation, hence avoiding third software party necessary in the loose-coupling approach, makes model building faster with respect to other software intended for the same purposes. Also, integration in QGIS makes FREEWAT particularly convenient in terms of working in a unique environment, where the geographic component of the involved processes can be fully taken into account. This holds especially true when geographic-integrated datasets (e.g., digital elevation models, land use, geological and hydrogeological maps) need to be consulted for a thorough comprehension of the investigated systems. In this regards, the possibility to use web services in the QGIS desktop to visualize and use maps containing spatial information (e.g., ortophoto, 
outcomes from climate projection models) is relevant, also to guarantee increased flexibility in the use of the GIS interface and frequent data updating.

6. The presence of pre- and post-processing tools and tools for model implementation, as those for converting information in raster and vector data format into model data objects [17], facilitates model construction. This is also true for the akvaGIS and OAT tools for pre- and post-processing of time-series data distributed in space, especially in complex hydrogeological settings.

7. A further keypoint is given by the fact that, for simulation purposes, FREEWAT mostly relies on well-documented and widely used (at global scale) codes for modeling ground- and surface-water interaction, such as those of the MODFLOW-USGS family and related codes.

8. The user-friendliness of the FREEWAT platform is considered a strength, as model implementation results from pretty straightforward processes. In this framework, the broad availability of detailed documentation (Reference and User Manuals and Tutorials [17]) is highly appreciated by those entering in contact with the FREEWAT suite. The case study applications were made smooth also thanks to the available materials. The case study experiences served as a testing phase during the implementation of the FREEWAT platform, as they allowed to identify deficiencies/bugs and to devise future development perspectives, even besides the end of the H2020 FREEWAT project.

\section{Conclusions}

The objective of this paper was to demonstrate how open source tools, such as the FREEWAT platform, may effectively support groundwater resource management, when using spatially distributed data and rigorous technical scientific analysis. We presented some modelling experiences where the FREEWAT platform was applied to investigate relevant groundwater management issues: (i) assessing the current status of groundwater bodies with respect to quantity and quality; (ii) identifying the major processes and stresses involved in the maintenance or alteration of such status; (iii) exploiting information contained in the available data, even in case of data scarcity; (iv) projecting the impacts of climate change and groundwater management measures over the medium and long term to ensure the sustainability of groundwater resources use.

Integration of the FREEWAT platform in the QGIS desktop is considered its major strength, as well as an outstanding benefit for its application to groundwater resource management issues.

The FREEWAT platform can be considered a valuable tool, either from the perspective of experts/policy-makers to support decision-making, and from the point of view of scientists to address GWRM issues. The main advantage is probably that the FREEWAT platform integrates, in a unique environment, capabilities that cannot be found easily in any other existing software tool developed for the same purposes.

In this sense, compared to other existing software solutions, FREEWAT embeds data analysis and visualization tools which allow each step of the modelling workflow to be accomplished, i.e., from data analysis, to conceptual model definition, to numerical modelling and reporting of models' results. Such tools are further complemented by GIS functionalities, which is particularly convenient, because of the possibility to organize, aggregate and manage large amounts of spatial and temporal data in a rigorous way, thus allowing integration of the spatial component in data analysis and model implementation.

Finally, the presented experiences demonstrate that improved access to spatial data and the portability of models and models' results can help to reduce the cooperation gap among water managers and to promote groundwater sustainability from the local to the basin scale. FREEWAT may represent a valuable tool to target the objective of increasing the capabilities of public authorities and private companies to manage water resources by means of up-to-date, robust, well-documented and reliable software, without entailing the need for costly licensing, while providing the chance for developing tailored applications.

Author Contributions: Conceptualization, R.R., I.B., M.C. and L.F.; methodology, all authors; software, I.B., M.C., L.F., R.R. and G.D.F.; all other authors contributed to bugs notification; validation, all authors; formal analysis, all authors; investigation, all authors; resources, all authors; data curation, all authors; writing-original draft 
preparation, G.D.F. and R.R.; all other authors contributed to revising the text for the specific case study they were responsible for; writing - review and editing, G.D.F. and R.R.; visualization, G.D.F. and R.R.; all other authors contributed to revising the text for the specific case study they were responsible for; project administration, R.R.; funding acquisition, R.R. All authors have read and agreed to the published version of the manuscript.

Funding: This research was funded by the European Union within the Horizon 2020 research and innovation programme, H2020 FREEWAT project (2015-2017), grant number 642224. The APC was funded by Scuola Superiore Sant'Anna.

Conflicts of Interest: The authors declare no conflict of interest.

\section{References}

1. Acheampong, E.N.; Swilling, M.; Urama, K. Developing a framework for supporting the implementation of integrated water resource management (IWRM) with a decoupling strategy. Water Policy 2016, 18, 1317-1333. [CrossRef]

2. Quevauviller, P.; Batelaan, O.; Hunt, R.J. Groundwater regulation and integrated water planning. In Integrated Groundwater Management; Springer: Cham, Switzerland, 2016; pp. 197-227.

3. EU. Directive 2000/60/EC of the European Parliament and of the Council establishing a framework for the Community action in the field of water policy. Off. J. Eur. Commun. 2000, 22, 2000.

4. EU. Directive 2006/118/EC of the European Parliament and the Council of 12th of December 2006 on the Protection of Ground Water against Pollution and Deterioration. Off. J. Eur. Union L 2006, 372, 19-31.

5. Karkkainen, B.C. Managing transboundary aquatic ecosystems: Lessons from the Great Lakes. Pac. McGeorge Glob. Bus. Dev. Law J. 2006, 19, 209.

6. Kralisch, S.; Böhm, B.; Böhm, C.; Busch, C.; Fink, M.; Fischer, C.; Schwartze, C.; Selsam, P.; Zander, F.; Flügel, W.A. ILMS-A Software Platform for Integrated Environmental Management. In Proceedings of the 6th International Congress on Environmental Modelling and Software, Liepzig, Germany, 5 June-1 July 2012.

7. Alcaraz, M.; Vázquez-Suñé, E.; Velasco, V.; Criollo, R. A loosely coupled GIS and hydrogeological modeling framework. Environ. Earth Sci. 2017, 76, 382. [CrossRef]

8. Bhatt, G.; Kumar, M.; Duffy, C.J. A tightly coupled GIS and distributed hydrologic modeling framework. Environ. Model. Softw. 2014, 62, 70-84. [CrossRef]

9. Carrera-Hernandez, J.J.; Gaskin, S.J. The groundwater modeling tool for GRASS (GMTG): Open source groundwater flow modeling. Comput. Geosci. 2006, 32, 339-351. [CrossRef]

10. Crestaz, E.; Pellegrini, M.; Schätzl, P. Tight-coupling of groundwater flow and transport modelling engines with spatial databases and GIS technology: A new approach integrating FEFLOW in ARCgis. Acque Sotter. Ital. J. Groundw. 2012, 2, 29-38. [CrossRef]

11. Dile, Y.T.; Daggupati, P.; George, C.; Srinivasan, R.; Arnold, J. Introducing a new open source GIS user interface for the SWAT model. Environ. Model. Softw. 2016, 85, 129-138. [CrossRef]

12. Lei, X.; Wang, Y.; Liao, W.; Jiang, Y.; Tian, Y.; Wang, H. Development of efficient and cost-effective distributed hydrological modeling tool MWEasyDHM based on open-source MapWindow GIS. Comput. Geosci. 2011, 37, 1476-1489. [CrossRef]

13. Rossetto, R.; Borsi, I.; Schifani, C.; Bonari, E.; Mogorovich, P.; Primicerio, M. SID\&GRID: Integrating hydrological modeling in GIS environment. Rend. Online Soc. Geol. Ital. 2013, 24, 282-283.

14. Strassberg, G.; Maidment, D.R.; Joens, N. Arc Hydro Groundwater Data Model. In Proceedings of the ESRI International User Conference, San Diego, CA, USA, 25-29 July 2005.

15. Wang, L.; Jackson, C.R.; Pachocka, M.; Kingdon, A. A seamlessly coupled GIS and distributed groundwater flow model. Environ. Model. Softw. 2016, 82, 1-6. [CrossRef]

16. Borsi, I.; Rossetto, R.; Schifani, C.; Hill, M.C. Modeling unsaturated zone flow and runoff processes by integrating MODFLOW-LGR and VSF, and creating the new CFL package. J. Hydrol. 2013, 488, 33-47. [CrossRef]

17. Rossetto, R.; De Filippis, G.; Borsi, I.; Foglia, L.; Cannata, M.; Criollo, R.; Vázquez-Suñé, E. Integrating free and open source tools and distributed modelling codes in GIS environment for data-based groundwater management. Environ. Model. Softw. 2018, 107, 210-230. [CrossRef]

18. Rossetto, R.; De Filippis, G.; Triana, F.; Ghetta, M.; Borsi, I.; Schmid, W. Software tools for management of conjunctive use of surface- and ground-water in the rural environment: Integration of the Farm Process and the Crop Growth Module in the FREEWAT platform. Agric. Water Manag. 2019, 223. [CrossRef] 
19. Criollo, R.; Velasco, V.; Nardi, A.; de Vries, L.M.; Riera, C.; Scheiber, L.; Jurado, A.; Brouyère, S.; Pujades, E.; Rossetto, R.; et al. AkvaGIS: An open source tool for water quantity and quality management. Comput. Geosci. 2018, 127, 123-132. [CrossRef]

20. QGIS Development Team. QGIS Geographic Information System, Open Source Geospatial Foundation Project. 2009. Available online: http://qgis.osgeo.org (accessed on 1 December 2019).

21. FloPy. A Python Package to Create, Run and Post-process MODFLOW-based Models. 2016. Available online: http://modflowpy.github.io/flopydoc/ (accessed on 1 January 2019).

22. Bakker, M.; Post, V.; Langevin, C.D.; Hughes, J.D.; White, J.T.; Starn, J.J.; Fienen, M.N. Scripting MODFLOW model development using Python and FloPy. Groundwater 2016. [CrossRef]

23. Bakker, M.; Post, V.; Langevin, C.D.; Hughes, J.D.; White, J.T.; Starn, J.J.; Fienen, M.N. United States Geological Survey Software Release; FloPy v3.2.8.; USGS: Reston, VA, USA, 2017. [CrossRef]

24. SpatiaLite Development Team. The Gaia-Sins Federated Projects Home-Page. 2011. Available online: http://www.gaia-gis.it/gaia-sins/ (accessed on 1 January 2019).

25. Cannata, M.; Neumann, J. The Observation Analysis Tool: A free and open source tool for time series analysis for groundwater modeling. Geoing. Ambient. Min. 2017, 151, 51-56.

26. Harbaugh, A.W. MODFLOW-2005, The United States Geological Survey Modular Groundwater Model-The Ground-Water Flow Process; Techniques and Methods 6-A16; USGS: Reston, VA, USA, 2005.

27. Hanson, R.T.; Boyce, S.E.; Schmid, W.; Hughes, J.D.; Mehl, S.W.; Leake, S.A.; Maddock, T.; Niswonger, R.G. One-Water Hydrologic Flow Model (MODFLOW-Owhm); Techniques and Methods 6-A51; No. 6-A51; USGS: Reston, VA, USA, 2014.

28. Williams, J.R.; Jones, C.A.; Kiniry, J.R.; Spanel, D.A. The epic crop growth-model. Trans. ASAE 1989, 32, 497-511. [CrossRef]

29. Gassman, P.W.; Williams, J.R.; Benson, V.W.; Izaurralde, R.C.; Hauck, L.M.; Jones, C.A.; Atwood, J.D.; Kiniry, J.R.; Flowers, J.D. Historical Development and Applications of the EPIC and APEX Models. In Proceedings of the 2004 ASAE Annual Meeting (P. 1), American Society of Agricultural and Biological Engineers, 2005; Available online: https:/elibrary.asabe.org/abstract.asp?aid=17074 (accessed on 18 December 2019).

30. Pollock, D.W. User Guide for MODPATH Version 7-A Particle-Tracking Model for MODFLOW; Open-File Report 2016-1086; USGS: Reston, VA, USA, 2016; p. 35.

31. Harbaugh, A.W. A Computer Program for Calculating Subregional Water Budgets Using Results from the U.S. Geological Survey Modular Three-dimensional Groundwater Flow Model; Open-File Report 90-392; USGS: Reston, VA, USA, 1990; p. 46.

32. Zheng, C.; Wang, P.P. MT3DMS, a Modular Three-Dimensional Multi-Species Transport Model for Simulation of Advection, Dispersion and Chemical Reactions of Contaminants in Groundwater Systems; Contract Report SERDP-99-1; U.S. Army Engineer Research and Development Center: Vicksburg, MS, USA, 1999; p. 202.

33. Bedekar, V.; Morway, E.D.; Langevin, C.D.; Tonkin, M. MT3D-USGS Version 1: A U.S. Geological Survey Release of MT3DMS Updated with New and Expanded Transport Capabilities for Use with MODFLOW; Techniques and Methods 6-A53; USGS: Reston, VA, USA, 2016; p. 69.

34. Borsi, I.; Foglia, L.; Cannata, M.; Vázquez-Suñé, E.; Mehl, S.; De Filippis, G.; Criollo, R.; Ghetta, M.; Cardoso, M.; Velasco, V.; et al. FREEWAT User Manual; Volume 0-Reference Manual; Version 1.2.0; FREEWAT Development Team: Pisa, Italy, 2019.

35. Langevin, C.D.; Thorne, D.T., Jr.; Dausman, A.M.; Sukop, M.C.; Weixing, G. SEAWAT Version 4: A Computer Program for Simulation of Multi-species Solute and Heat Transport; Techniques and Methods 6-A22; USGS: Reston, VA, USA, 2007; p. 39.

36. Poeter, E.P.; Hill, M.C.; Dan, L.; Tiedeman, C.R.; Mehl, S. UCODE_2014, with New Capabilities to Define Parameters Unique to Predictions, Calculate Weights Using Simulated Values, Estimate Parameters with SVD, Evaluate Uncertainty with MCMC, and More; Integrated Groundwater Modeling Center Report Number: GWMI 2014-02; Integrated Groundwater Modeling Center (IGWMC) of the Colorado School of Mines; 2014. Available online: https://pubs.er.usgs.gov/publication/70159674 (accessed on 18 December 2019).

37. Mahmoodzadeh, D.; Ketabchi, H.; Ataie-Ashtiani, B.; Simmons, C.T. Conceptualization of a fresh groundwater lens influenced by climate change: A modeling study of an arid-region island in the Persian Gulf, Iran. J. Hydrol. 2014, 519, 399-413. [CrossRef]

38. Singh, A. Optimization modelling for seawater intrusion management. J. Hydrol. 2014, 508, 43-52. [CrossRef] 
39. Bakker, M. Analytic solutions for interface flow in combined confined and semi-confined, coastal aquifers. Adv. Water Resour. 2006, 29, 417-425. [CrossRef]

40. Yeh, W.G. Review: Optimization methods for groundwater modeling and management. Hydrogeol. J. 2015, 23, 1051-1065. [CrossRef]

41. Post, V.; Abarca, E. Preface: Saltwater and freshwater interactions in coastal aquifers. Hydrogeol. J. 2010, 18, 1-4. [CrossRef]

42. Singh, A. Managing the environmental problem of seawater intrusion in coastal aquifers through simulation-optimization modeling. Ecol. Indic. 2015, 48, 498-504. [CrossRef]

43. Gigliuto, A.; Righetti, C.; Chini, A.; Rossetto, R. Numerical groundwater flow modelling for remediation design and seawater intrusion assessment at a coastal industrial site. IAHS AISH 2011, 341, 179-183.

44. Sapiano, M.; Schembri, M.; Debattista, H.; Theuma, N. Integrating numerical models in river basin management plans: The FREEWAT project. WIT Trans. Ecol. Environ. 2017, 220, 227-238.

45. Government of Malta. The 2nd Water Catchment Management Plan for the Malta Water Catchment District; Government of Malta: Valletta, Malta, 2016.

46. Distretto Appennino Settentrionale. Piano di Gestione Delle Acque ex art 13, c. 7 Dir. 2000/60/CE e art. 117 D.Lgs 152/2006. Aggiornamento del Piano II Ciclo. Relazione di Piano.-River Basin Management Plan ex art. 13 c. 7 Dir. 2000/60/CE and art. 117 D.Lgs 152/2006. 2nd Cycle Plan Update. Plan Report. 2016. Available online: http://www.appenninosettentrionale.it/itc/?page_id=769 (accessed on 1 March 2017).

47. Positano, P.; Nannucci, M. The H2O20 FREEWAT participated approach for the Follonica-Scarlino aquifer case study. A common space to generate shared knowledge on the value of water. Acque Sotter. Ital. J. Groundw. 2017, 6. [CrossRef]

48. Regione Toscana. Manuale di utilizzo del sistema WebGIS Geoscopio. 2017. Available online: http: //www502.regione.toscana.it/geoscopio/documenti/guida_uso/pdf/geoscopio_help_page.pdf (accessed on 1 December 2019).

49. Pouliaris, C.; Perdikaki, M.; Foglia, L.; Schüth, C.; Kallioras, A. Hydrodynamic analysis of a Mediterranean aquifer system with the use of hydrochemical and isotopical analysis as supporting tools. Environ. Earth Sci. 2018, 77, 237. [CrossRef]

50. Barthel, R.; Banzhaf, S. Groundwater and surface water interaction at the regional-scale-a review with focus on regional integrated models. Water Resour. Manag. 2016, 30, 1-32. [CrossRef]

51. Rautio, A.; Korkka-Niemi, K. Chemical and isotopic tracers indicating groundwater/surface-water interaction within a boreal lake catchment in Finland. Hydrogeol. J. 2015, 23, 687-705. [CrossRef]

52. Cantor, A.; Owen, D.; Harter, T.; Nylen, N.G.; Kiparsky, M. Navigating Groundwater-Surface Water Interactions under the Sustainable Groundwater Management Act; Berkeleylaw University of California: Berkeley, CA, USA, 2018.

53. Tian, Y.; Zheng, Y.; Wu, B.; Wu, X.; Liu, J.; Zheng, C. Modeling surface water-groundwater interaction in arid and semi-arid regions with intensive agriculture. Environ. Model. Softw. 2015, 63, 170-184. [CrossRef]

54. Wu, X.; Zheng, Y.; Wu, B.; Tian, Y.; Han, F.; Zheng, C. Optimizing conjunctive use of surface water and groundwater for irrigation to address human-nature water conflicts: A surrogate modeling approach. Agric. Water Manag. 2016, 163, 380-392. [CrossRef]

55. Dillon, P.; Pavelic, P.; Nava, A.P.; Weiping, W. Advances in multi-stage planning and implementing managed aquifer recharge for integrated water management. Sustain. Water Resour. Manag. 2018. [CrossRef]

56. Dillon, P.; Stuyfzand, P.; Grischek, T.; Lluria, M.; Pyne, R.D.G.; Jain, R.C.; Bear, J.; Schwarz, J.; Wang, W.; Fernandez, E.; et al. Sixty years of global progress in managed aquifer recharge. Hydrogeol. J. 2019, 27, 1-30. [CrossRef]

57. Rossetto, R.; Barbagli, A.; Borsi, I.; Mazzanti, G.; Vienken, T.; Bonari, E. Site investigation and design of the monitoring system at the Sant'Alessio Induced RiverBank Filtration plant (Lucca, Italy). Rend. Online Soc. Geol. Ital. 2015, 35, 248-251.

58. Kopač, I.; Vremec, M. Slovenian test case Vrbanski Plato aquifer in the EU HORIZON 2020 FREEWAT project. Acque Sotter. Ital. J. Groundw. 2017, 6. [CrossRef]

59. Kahuda, D.; Boukalova, Z.; Vojík, P.; Čejka, F. Report on the Application of FREEWAT to Velké Žernoseky Case Study; Appendix 5 to Deliverable 4.1 of the H2020 FREEWAT Project; Methodology Centre for Environment Assessment: Prague, Czech Republic, 2017.

60. Dadaser-Celik, F.; Celik, M. Modelling surface water-groundwater interactions at the Palas Basin (Turkey) using FREEWAT. Acque Sotter. Ital. J. Groundw. 2017, 6. [CrossRef] 
61. Green, T.R.; Taniguchi, M.; Kooi, H.; Gurdak, J.J.; Allen, D.M.; Hiscock, K.M.; Treider, H.; Aureli, A. Beneath the surface of global change: Impacts of climate change on groundwater. J. Hydrol. 2011, 405, 532-560. [CrossRef]

62. Taylor, R.G.; Scanlon, B.; Döll, P.; Rodell, M.; Van Beek, R.; Wada, Y.; Longuevergne, L.; Leblanc, M.; Famiglietti, J.S.; Edmunds, M.; et al. Ground water and climate change. Nat. Clim. Chang. 2013, 3, 322. [CrossRef]

63. Hanson, R.T.; Flint, L.E.; Flint, A.L.; Dettinger, M.D.; Faunt, C.C.; Cayan, D.; Wolfgang, S. A method for physically based model analysis of conjunctive use in response to potential climate changes. Water Resour. Res. 2012, 48. [CrossRef]

64. Panteleit, B.; Jensen, S.; Seiter, K.; Siebert, Y. Das Bremerhavener Grundwasser im Klimawandel—Eine FREEWAT-Fallstudie. Grundwasser 2018, 23, 233-244. [CrossRef]

65. Pandele, A.; Serpescu, I.; Radu, E.; Minciuna, M. Utilization of the FREEWAT platform - free open-source tool for groundwater resource management, within pilot area Banat plain. Int. Multidiscip. Sci. GeoConf. SGEM 2017, 17, 977-984.

66. Van der Gun, J. Transboundary Groundwater Resources: Sustainable Management and Conflict Resolution; Lap Lambert Academic Publishing: Saarbrücken, Germany, 2018.

67. IGRAC. Available online: https://www.un-igrac.org/sites/default/files/resources/files/TBAmap_2015.pdf (accessed on 23 October 2019).

68. Lee, E.; Jayakumar, R.; Shrestha, S.; Han, Z. Assessment of transboundary aquifer resources in Asia: Status and progress towards sustainable groundwater management. J. Hydrol. Reg. Stud. 2018, 20, 103-115. [CrossRef]

69. Nijsten, G.J.; Christelis, G.; Villholth, K.G.; Braune, E.; Gaye, C.B. Transboundary aquifers of Africa: Review of the current state of knowledge and progress towards sustainable development and management. J. Hydrol. Reg. Stud. 2018, 20, 21-24. [CrossRef]

70. CIPAIS. CIPAIS Pannello di Controllo sullo stato e sull'evoluzione delle acque del Lago di Lugano. Rapporto dell'Agosto 2012; Commissione Internazionale per la Protezione delle Acque Italo Svizzere. 2012. Available online: http: //www.cipais.org/pdf/comunicati-stampa/Pannello\%20Lago\%20Lugano\%202015_1_sett\%202016.pdf (accessed on 18 December 2019).

71. Cannata, M.; Neumann, J.; Rossetto, R. Open source GIS platform for water resource modelling: FREEWAT approach in the Lugano Lake. Spat. Inf. Res. 2017, 26, 241-251. [CrossRef]

72. IGRAC, UNESCO-IHP. Guidelines for Multi-Disciplinary Assessment of Transboundary Aquifers—Draft Version; IGRAC: Delft, The Netherlands, 2015.

73. JICA Study Team. The Study on the Groundwater Potential Evaluation and Management Plan in the Southeast Kalahari (Stampriet) Artesian Basin in the Republic of Namibia; Draft Final Report to the Department of Water Affairs, Ministry of Agriculture, Water and Rural Development, Republic of Namibia, submitted by Pacific Consultants International; in Association with Sanyu Consultants Inc.; JICA: Tokyo, Japan, 2002.

74. UNESCO. Stampriet Transboundary Aquifer System Assessment-Governance of Groundwater Resources in Transboundary Aquifers (GGRETA)_Phase 1; UNESCO: Paris, France, 2016.

75. Siebert, S.; Henrich, V.; Frenken, K.; Burke, J. Update of the Digital Global Map of Irrigation Areas to Version 5, Rheinische Friedrich-Wilhelms-Universität; Bonn; Germany and Food and Agriculture Organization of the United Nations: Rome, Italy, 2013.

76. Connor, R. The United Nations World Water Development Report 2015: Water for a Sustainable World; UNESCO: Paris, France, 2015; Volume 1.

77. Stuyfzand, P.J. The impact of land reclamation on groundwater quality and future drinking water supply in the Netherlands. Water Sci. Technol. 1995, 31, 47-57. [CrossRef]

78. Guo, H.; Jiao, J.J. Impact of coastal land reclamation on ground water level and the sea water interface. Groundwater 2007, 45, 362-367. [CrossRef]

79. Bertrand, G.; Goldscheider, N.; Gobat, J.M.; Hunkeler, D. From multi-scale conceptualization to a classification system for inland groundwater-dependent ecosystems. Hydrogeol. J. 2012, 20, 5-25. [CrossRef]

80. Doody, T.M.; Barron, O.V.; Dowsley, K.; Emelyanova, I.; Fawcett, J.; Overton, I.C.; Pritchard, J.L.; Van Dijk, A.I.J.M.; Warren, G. Continental mapping of groundwater dependent ecosystems: A methodological framework to integrate diverse data and expert opinion. J. Hydrol. Reg. Stud. 2017, 10, 61-81. [CrossRef] 
81. Grodzynskyi, M.; Svidzinska, D. Modelling the impact of rural land use scenarios on water management: A FREEWAT approach to the Bakumivka catchment case study, Ukraine. Acque Sotter. Ital. J. Groundw. 2017, 6. [CrossRef]

82. Silvestri, N.; Pistocchi, C.; Sabbatini, T.; Rossetto, R.; Bonari, E. Diachronic analysis of farmers' strategies within a protected area of central Italy. Ital. J. Agron. 2012, 7:e20, 139-145. [CrossRef]

83. Rossetto, R.; Basile, P.; Cannavò, S.; Pistocchi, C.; Sabbatini, T.; Silvestri, N.; Bonari, E. Surface water and groundwater monitoring and numerical modeling of the southern sector of the Massaciuccoli Lake basin (Italy). Rend. Online Soc. Geol. Ital. 2010, 11, 189-190.

84. Pistocchi, C.; Silvestri, N.; Rossetto, R.; Sabbatini, T.; Guidi, M.; Baneschi, I.; Bonari, E.; Trevisan, D. A simple model to assess nitrogen and phosphorus contamination in ungauged surface drainage networks: Application to the Massaciuccoli Lake Catchment, Italy. J. Environ. Qual. 2012, 41, 544-553. [CrossRef] [PubMed]

85. Marandi, A.; Karro, E.; Polikarpus, M.; Jõeleht, A.; Kohv, M.; Hang, T.; Hiiemaa, H. Simulation of the hydrogeologic effects of oil-shale mining on the neighbouring wetland water balance: Case study in north-eastern Estonia. Hydrogeol. J. 2013, 21, 1581-1591. [CrossRef]

86. EU. Directive 92/43/EEC of the Council Directive on the conservation of natural habitats and of wild fauna and flora. Off. J. OJ L 206/7 1992, 7, 1-9.

87. Perdikaki, M.; Pouliaris, C.; Borsi, I.; Rossetto, R.; Kallioras, A. Management of coastal hydrosystems through the application of free and open source software tool FREEWAT. Eur. Water 2017, 57, 383-388.

88. Koltsida, E.; Kallioras, A. Groundwater flow simulation through the application of the FREEWAT modeling platform. J. Hydroinform. 2019, 21, 812-833. [CrossRef]

(C) 2019 by the authors. Licensee MDPI, Basel, Switzerland. This article is an open access article distributed under the terms and conditions of the Creative Commons Attribution (CC BY) license (http://creativecommons.org/licenses/by/4.0/). 